UDC 903.53“638”-055.2(478)

Submitted: 17.02 .2020

LBC T442.7(2)-41

Accepted: 29.04 .2020

\title{
BARROW 11 OF THE "GARDEN" GROUP IN THE LOWER DNIESTER REGION AND CONTEMPORARY "MYTHMAKING" ABOUT SCYTHIAN "AMAZONS"
}

\author{
Vitalij S. Sinika \\ Pridnestrovian State University, Tiraspol, Pridnestrovie, Moldova
}

Sergey D. Lysenko

Institute of Archaeology, National Academy of Sciences of Ukraine, Kiev, Ukraine

Sergey N. Razumov

Pridnestrovian State University, Tiraspol, Pridnestrovie, Moldova

Nikolaj P. Telnov

Institute of Cultural Heritage, Kishinev, Moldova

Sylwia Lukasik

Adam Mickiewicz University, Poznań, Poland

\begin{abstract}
The article publishes and analyzes materials obtained during the study of the Scythian barrow 11 of the "Garden" group excavated in 2018 near village Glinoe, Slobodzeya district, on the left bank of the Lower Dniester, for the first time. The barrow was surrounded by a circular ditch and contained four burials one infant and three female. The tools from the barrow are represented by knives, spindle-whorls, needle. The only piece of tableware was found and it was a wooden bowl. The adornments (a pair of earrings, two bead necklaces, one bead bracelet, two "elbow bracelets") were also discovered. Earrings with conical bulges on one of the endings testify to the Thracian influence on the material culture of the Scythians of the North-West Black Sea region. All female graves contained mirrors. Two of them are identical, and both were laid under the body of the buried. One of the mirrors has handle aforethoughtly broken in antiquity. The cult objects are a pendant made of a dog's tooth and a stone slab, the arrowheads are the only weapons. The barrow dates back to the second half (preferably the third quarter) of the $4^{\text {th }}$ century BC. Finding a quiver set in the grave 4 of barrow 11 of Glinoe/"Garden" group made the authors to analyze the burials of the so-called Scythian "amazons" of the North Black Sea region. It turned out that many of them were attributed with flagrant violations of scientific methods as burials of women-warriors, which is nothing more than modern "myth-making". As a result, the $\therefore$ authors claim that an open-minded analysis allows us to distinguish three groups of Scythian burials with U. weapons: 1) containing weapons, placement of which reflects certain "ethnographic" features of the rite or the o special status of buried; 2) containing arrowheads that may indicate hunting; 3 ) the burials of warriors with diverse and numerous weapons.
\end{abstract}

Key words: Left bank of the Lower Dniester, Scythians, barrow, graves, third quarter of the $4^{\text {th }}$ century BC, weapons, adornments, tools, mirrors, stone slab, "mythmaking", "amazons".

Citation. Sinika V.S., Lysenko S.D., Razumov S.N., Telnov N.P., Łukasik S., 2020. Barrow 11 of the "Garden" Group in the Lower Dniester Region and Contemporary "Mythmaking" About Scythian "Amazons". The Lower Volga Archaeological Bulletin, vol. 19, no. 1, pp. 64-101. (in Russian). DOI: https://doi.org/10.15688/nav. jvolsu.2020.1.4 


\title{
КУРГАН 11 ГРУППЫ «САД» В НИЖНЕМ ПОДНЕСТРОВЬЕ И СОВРЕМЕННОЕ «МИФОТВОРЧЕСТВО» О СКИФСКИХ «АМАЗОНКАХ»
}

\author{
Виталий Степанович Синика
}

Приднестровский государственный университет, г. Тирасполь, Приднестровье, Молдова

\section{Сергей Дмитриевич Лысенко}

Институт археологии Национальной академии наук Украины, г. Киев, Украина

\section{Сергей Николаевич Разумов}

Приднестровский государственный университет, г. Тирасполь, Приднестровье, Молдова

\section{Николай Петрович Тельнов}

Институт культурного наследия, г. Кишинев, Молдова

\section{Сильвия Лукасик}

Университет им. А. Мицкевича, г. Познань, Польша

Аннотация. В статье впервые публикуются и анализируются материалы, полученные при исследовании скифского кургана 11 группы Глиное/Сад на левобережье Нижнего Днестра. Курган был окружен кольцевым рвом и содержал четыре захоронения - одно детское и три женских. Орудия труда из кургана представлены ножами, пряслицами, иглой, посуда - деревянной миской, украшения - парой серег, двумя ожерельями из бусин, одним браслетом из бусин, двумя «локтевыми браслетами». Серьги с коническими утолщениями на одном из окончаний свидетельствуют о фракийском влиянии на материальную культуру скифов Северо-Западного Причерноморья. Во всех женских захоронениях были зеркала. Два из них идентичны, и оба были положены под тела погребенных. У одного из зеркал в древности преднамеренно отломана ручка. Предметами культа являются подвеска из зуба собаки и каменная плита, вооружением - только наконечники стрел. Курган датируется второй половиной (предпочтительно третьей четвертью) IV в. до н.э. Находка колчанного набора в погребении 4 кургана 11 группы Глиное/Сад заставила авторов проанализировать погребения так называемых скифских «амазонок» Северного Причерноморья. Оказалось, многие из них атрибутированы как погребения женщин-воинов с грубейшими нарушениями научной методики, что является не более чем современным «мифотворчеством». В результате мы констатируем, что непредвзятый анализ позволяет различать три группы скифских захоронений с оружием: 1) с предметами вооружения, размещение которых отражает определенные «этнографические» особенности обряда или особый статус погребенных; 2) с наконечниками стрел, которые могут свидетельствовать об охотничьем промысле; 3) погребения воинов с разнообразными и многочисленными предметами вооружения.

Ключевые слова: левобережье Нижнего Днестра, скифы, курган, погребения, третья четверть IV в. до н.э., предметы вооружения, украшения, орудия труда, зеркала, каменная плита, «мифотворчество», «амазонки».

Цитирование. Синика В. С., Лысенко С. Д., Разумов С. Н., Тельнов Н. П., Лукасик С., 2020. Курган 11 группы «Сад» в Нижнем Поднестровье и современное «мифотворчество» о скифских «амазонках» // Нижневолжский археологический вестник. Т. 19, № 1. С. 64-101. DOI: https://doi.org/10.15688/nav.jvolsu.2020.1.4 
«Приходится констатировать, что ошибочные утверждения, тем более высказанные неоднократно, никем не оспоренные и не оспариваемые, со временем “по умолчанию” приобретают видимость непреложных истин. Такие “истины” в дальнейшем становятся отправной точкой тех или иных научных построений, фундамента которых просто не существует» [Тельнов, Синика, 2013, с. 306].

\section{Введение}

К настоящему времени в Нижнем Поднестровье изучены сотни скифских захоронений, при этом их большая часть была исследована за последние 25 лет. Особенно результативными оказались работы Днестровской археологической экспедиции у с. Глиное Слободзейского района на левобережье Нижнего Днестра. Здесь с 1995 по 2019 г. было исследовано более 250 скифских захоронений, и значительная их часть введена в научный оборот [Синика, Тельнов, 2016а; 2016б; 2016в; 2017a; 2017б; 2017в; 2018а; 2018б; Тельнов и др., 2016; Sinika et al., 2017; Синика и др., 2017; Синика и др., 2018а; 2018б; 2018в; 2018г; 2018д; 2018е; Синика и др., 2019а; 2019б; 2019в; 2019г; Синика и др., 2020].

Тем не менее публикация новых материалов из Поднестровья представляется актуальной, поскольку имеет значение для изучения истории скифской культуры всего Северного Причерноморья.

В настоящей работе впервые публикуются и анализируются материалы, полученные в 2018 г. при исследовании скифского кургана 11 группы «Сад» 1 . Памятник находился в 2,75 км к ССВ от северной оконечности с. Глиное Слободзейского района, на высоком плато, расположенном на правом берегу p. Красная. Ниже приводится описание этого кургана, исследованных в нем скифских погребений, а также сопровождающего инвентаря.

\section{Описание комплекса}

Курган 11 группьь «Сад» копался параллельными траншеями с использованием техники. Была разбита одна бровка по линии 3-В шириной 0,6 м, длиной 20 м (рис. 1,1).
Насыпь полностью уничтожена распашкой. В непосредственной близости от нее найдены керамическое лощило (1) и камень (2).

Описание находок.

1. Лощило, изготовленное из ручки гераклейской амфоры. Один торец сточен под углом около $20^{\circ}$ в сторону внутренней поверхности. Тесто с примесью мелкого шамота, песка. Цвет оранжевый. Поверхности шероховато-заглаженные. Длина фрагмента 119 мм. Размеры верхнего сечения $42 \times 24$ мм, нижнего $-40 \times 29$ мм. Размеры сточенной площадки $40 \times 30$ мм (рис. 1,2).

2. Каменное изделие («курант») неправильной подпрямоугольной формы размерами $53 \times 67 \times 70$ мм. Изготовлено из плотного сланца черного цвета с белыми прожилками (рис. 1,3).

В кургане обнаружены ров и четыре скифских захоронения.

Кольиевой ров диаметром 8,5 м, шириной до 0,5 м и глубиной до 0,81 м от $R_{0}$ был сооружен одновременно с основными скифскими погребениями 3 и 4. Ров в сечении подтрапециевидный. В западной и восточной частях рва были оставлены два разрыва шириной 2,5 и 2 м, находящиеся на линии 3Ю3BCB. В черноземном заполнении рва находки не обнаружены.

Погребение 1 (скифское, впускное) обнаружено в южной части кургана. Совершено в катакомбе (рис. 2,1,2).

Входная яма не прослежена, вероятно, она находилась южнее камеры.

Погребальная камера неправильной формы длиной 1 м и шириной 0,6 м была зафиксирована на глубине 0,64 м от $R_{0}$. Дно камеры зафиксировано на глубине 0,83 м от $R_{0}$. В западной части камеры отмечены остатки свода на высоте 0,17 м от дна.

На дне лежал костяк ребенка возрастом 3 года [Łukasik, 2019a, p. 2] в слабо скорченном положении на спине с разворотом на правый бок, головой на ЗЮЗ. Следов подстилки и инвентаря не обнаружено.

Погребение 2 (скифское, впускное) обнаружено в 6 м к С от $R_{0}$. Совершено в яме (рис. 2,3,4).

Контуры ямы прямоугольной формы размерами 2,15 × 0,85 м были зафиксированы на глубине 0,7 м от $R_{0}$. Яма была ориентирована 
по линии 3С3-ВЮВ, ее глубина от уровня обнаружения составила 0,85 м. Заполнение состояло преимущественно из чернозема.

Погребенный (возрастом 15-20 лет [Łukasik, 2019a, p. 2]; пол не был определен антропологом) лежал в вытянутом положении на спине, головой на ЗСЗ. Правая рука вытянута вдоль тела. Левая рука согнута в локте под прямым углом, кисть на поясничных позвонках. Ноги вытянуты. Под костями светло-серый тлен от органической подстилки.

Состав и расположение инвентаря. В западной части ямы лежали кости мелкого рогатого скота от жертвенной пищи и нож с роговой рукоятью (2). На шейных позвонках и под нижней челюстью обнаружены предметы ожерелья (3). На правом запястье находился браслет из бусин (4). Под левой лопаткой и позвоночником лежало бронзовое зеркало (1) рукоятью на С.

Описание находок.

1. Бронзовое зеркало с боковой трапециевидной ручкой, окончание которой оформлено в виде овального навершия. Общая длина зеркала 231 мм. Диаметр диска 135 × 137 мм. Длина ручки - 96 мм, ширина - 17-26 мм. Размеры овального навершия ручки $-21 \times 30$ мм. Толщина диска - до 1 мм, ручки - до 2 мм, навершия - 1,5-2 мм (рис. 2,7).

2. Железный нож с роговой рукоятью. Рукоять состоит из двух пластин, соединенных с черенком и между собой при помощи четырех заклепок (из которых двумя крепится к черенку). Лезвие обломано, треугольное в сечении. Длина сохранившейся части ножа до 150 мм. Длина остатков лезвия вместе с черенком - около 58 мм, длина черенка 39 мм. Ширина лезвия - до 20 мм. Толщина спинки лезвия - до 4 мм. Длина рукояти 132 мм. Размеры сечения рукояти на торце $15 \times 9$ мм, в средней части $-14,5 \times 13$ мм. Толщина рукояти у лезвия - до 14 мм. Ширина костяных пластин - 13-14 мм, толщина - 4-5 мм. Длина заклепок - до 17,5 мм, диаметр - около 4 мм; диаметр шляпок - 5-7 мм (рис. 2,6).

3. Ожерелье состояло из 13 стеклянных бусин и четырех стеклянных бисерин:

- биконическая бусина из горчичного непрозрачного стекла. Высота бусины 8,5 мм, диаметр - 9 мм. Диаметр конического отверстия - 1-1,5 мм (рис. 2,8a);
- поперечно-сжатая асимметричная бусина из синего полупрозрачного стекла. Высота бусины - 6,2 мм, диаметр - 9 мм. Диаметр отверстия - 3,5 мм (рис. 2,8б);

- цилиндрическая бусина из белого непрозрачного стекла (сохранился фрагмент). Высота бусины - 6,3 мм, диаметр - 6 мм. Диаметр отверстия - 2,5 мм (рис. 2,86);

- четыре четырехгранные пирамидальные подвески из синего полупрозрачного стекла. Высота подвесок - от 13 до 16 мм, размеры оснований - от 6,5 × 6,1 до 7,7 × 7,3 мм. Диаметр отверстий - от 1,3 мм до 1,5 мм (рис. 2,82);

- шесть асимметрично-сферических бусин из белого непрозрачного стекла. Высота бусин $-4,2-5$ мм, диаметр $-4,5-6$ мм. Диаметр конических отверстий - от 0,8-1 до 1,52 мм (рис. 2,8d);

- бисерина из розового стекла в виде топора. Размеры бисерины $-5,6 \times 3,3 \times 2,7$. Диаметр отверстия - 1,2 мм (рис. 2,8e);

- кольцевидная бисерина из белого непрозрачного стекла. Высота бисерины - 2 мм, диаметр - 4 мм. Диаметр отверстия - 1,2 мм (рис. 2,8ж);

- две кольцевидные бисерины из салатового непрозрачного стекла. Высота бисерин - 1,5 мм, диаметр - 3,4 мм. Диаметр отверстия - 1,5 мм (рис. 2,83).

4. Браслет на правом запястье состоял из восьми стеклянных бусин:

- уплощенно-сферическая бусина из белого полупрозрачного стекла. Высота бусины - 7,8 мм, диаметр - 12,5 мм. Диаметр отверстия - 5 мм (рис. 2,5a);

- цилиндрическая бусина из салатового непрозрачного стекла с белыми глазками и с горчичными зрачками. Высота бусины 8,4 мм, диаметр - 11,3 × 12,8 мм. Диаметр отверстия -6 мм (рис. 2,5б);

- тороидальная бусина из синего полупрозрачного стекла с белыми глазками. Высота бусины - 4,5 мм, диаметр - 8,4 × 9 мм. Диаметр отверстия -4 мм (рис. 2,58);

- две поперечно-сжатые асимметричные бусины из синего полупрозрачного стекла. Высота бусин - 7,5 и 6 мм, диаметр $10,6 \times 11$ и $9 \times 9,5$ мм. Диаметр отверстий 3,5 и 4 мм (рис. 2,52);

- две поперечно-сжатые асимметричные бусины из белого непрозрачного стекла. 
Высота бусин -6 и 5,3 мм, диаметр $-9 \times 9,5$ и $7,5 \times 7,7$ мм. Диаметр отверстий -4 и 3,5 мм (рис. 2,5d);

- бочонковидная бусина из белого непрозрачного стекла. Высота бусины - 6,5 мм, диаметр $-8,2$ мм. Диаметр отверстия - 3 мм (рис. 2,5e).

Погребение 3 (скифское, одно из основHblx) обнаружено в центре окруженного рвом подкурганного пространства, в 4,5 м к северу от $R_{0}$. Совершено в яме (рис. $3,1,2$ ).

Контуры ямы прямоугольной формы размерами 2,35 × 0,95 м были зафиксированы на глубине 0,74 м от $R_{0}$. Яма была ориентирована по линии 3С-В обнаружения составила 1,03 м. Заполнение состояло преимущественно из чернозема.

Погребение ограблено в древности. В придонной части заполнения встречались разрозненные кости женщины возрастом 20-30 лет [Łukasik, 2019a, p. 3]. Ее череп лежал теменем вверх на глубине 1,33 м от $R_{0}$ в центре ямы, кости конечностей - у западной и северной стен. Судя по сохранившимся in situ берцовым костям, женщина лежала в вытянутом положении на спине головой на ВЮВ.

Состав и расположение инвентаря. В придонном заполнении ямы были найдены лепное пряслице (1), бронзовый трехлопастный наконечник стрелы (3), пара бронзовых серег (4), стеклянные бусины (6) и две стеклянные подвески (7), амулет из зуба хищника (8). В восточной части ямы вместе с костями мелкого рогатого скота найдены фрагменты трех железных обивок деревянного сосуда (5). В заполнении ямы были также найдены мелкие фрагменты бронзового зеркала (2).

Описание находок.

1. Лепное оранжевоглиняное биконическое пряслице, с выраженным ребром посередине. Меньшее основание плоское, большее вогнутое. Тесто с примесью шамота, включениями мелкого песка, органики. Поверхность заглаженная. Высота пряслица -27 мм, максимальный диаметр - 27,5 мм. Диаметры оснований - 17 и 18 мм. Диаметр отверстия - 5,2 мм (рис. 3,7).

2. Три фрагмента бронзового зеркала размерами $35 \times 16$ мм. Толщина диска - 1 мм; к краю сужается до 0,5 мм (рис. 3,6 ).
3. Бронзовый трехлопастный наконечник стрелы с выступающей втулкой. Длина наконечника - 38 мм. Длина втулки - 10 мм, диаметр - 4,5 мм (рис. 3,3).

4. Пара бронзовых кольцевидных серег из круглой в сечении проволоки с разомкнутыми окончаниями. На одном из окончаний обеих серег конические утолщения. Диаметры серег - 39,5 × 35,5 и 33,5 × 35 мм, диаметр сечения проволоки - до 2 мм. Длина конических утолщений - 3,5 мм, диаметр - 2,5 и 3,2 мм (рис. $3,11,12$ ).

5. Две железные квадратные обивки деревянного сосуда. Вдоль двух противолежащих торцов расположено по три заклепки. Вдоль двух других торцов между крайними заклепками проделано по два дополнительных отверстия меньшего диаметра. Заклепки с грибовидными округлыми шляпками; нижняя часть стержня загнута. На внутренней поверхности пластин сохранились остатки дерева. Размеры пластин $-68 \times 65$ мм; толщина - до 3 мм, к краям сужаются. Длина заклепок до изгиба - не менее 15 мм. Диаметр заклепок до 3,5 мм, диаметр шляпок - 5-6 мм. Диметр маленьких отверстий $-1,5$ мм. Толщина дерева (стенки сосуда), к которому крепились пластины, около 10-11 мм (рис. 3,4,5).

6. Уплощенно-сферическая бусина из белого непрозрачного стекла (фрагмент). Высота бусины - 8,4 мм, диаметр - 11,5 мм. Диаметр отверстия - 3 мм (рис. 3,8 ).

7. Две четырехгранные пирамидальные подвески из синего полупрозрачного стекла. Высота подвесок - 17,6 и 15 мм. Размеры оснований $-6,4 \times 6,4$ и 6,5 × 6,2 мм; размеры верхних площадок $-3 \times 1,7$ и $2,5 \times 1$ мм. Диаметр конических отверстий $-1,5-2$ и $1,2-$ 1,8 мм (рис. 3,9,10).

8. Амулет-подвеска из коренного зуба собаки ${ }^{2}$. В одном из корневых отростков просверлено отверстие. Размеры изделия: $14,5 \times 10,2 \times 9,5$ мм. Диаметр отверстия $2,5$ мм (рис. 3,13$)$.

Погребение 4 (скифское, одно из основныlx) обнаружено в 3 м к С от $R_{0}$. Совершено в яме (рис. 4,1,2).

Контуры ямы прямоугольной формы размерами 2,35 × 0,9 м были зафиксированы на глубине 0,7 м от $R_{0}$. Яма была ориентирована по линии 3С-ВЮВ, ее глубина от уровня 
обнаружения составила 0,81 м. Заполнение состояло преимущественно из чернозема.

Костяк женщины возрастом 20-35 лет [Łukasik, 2019a, p. 3] лежал в вытянутом положении на спине, головой на ВЮВ. Руки слегка согнуты в локтях, кисти на тазобедренных суставах. Ноги вытянуты.

Состав и расположение инвентаря. В восточной части ямы лежали кости мелкого рогатого скота от жертвенной пищи и нож (6) с деревянной рукоятью. Южнее располагалась каменная плита с обожженной поверхностью (11). На шее найдены предметы ожерелья (8), на локтях - браслеты из бусин $(9,10)$. $\mathrm{y}$ правого локтя и у левого запястья почти вертикально, остриями вниз, на 11-12 см выше дна ямы располагалось по одному бронзовому трехлопастному наконечнику стрел $(3,4)$. Еще шесть наконечников (5) на той же глубине лежали в виде компактного скопления наклонно остриями вниз в 0,2 м севернее правой кисти (упали с перекрытия либо из подвешенного на вбитом в стенку колышке колчана). Под правой лопаткой лежало бронзовое зеркало (2) рукоятью на С (окончание ручки отломано в древности). Под зеркалом лежала железная игла (7). У левого колена найдено лепное пряслице (1).

Описание находок.

1. Лепное сероглиняное биконическое пряслице неправильной сферической формы. Тесто с примесью шамота и мелкого песка. Поверхность заглаженная. Высота пряслица 21,2 мм. Максимальный диаметр - 24,5 мм. Диаметры оснований - около 8 мм. Диаметр отверстия - 4,7-5 мм (рис. 4,7).

2. Бронзовое зеркало с боковой трапециевидной ручкой, окончание которой оформлено в виде овального навершия. Край диска местами выкрошен. Общая длина зеркала 231 мм. Диаметр диска - $150 \times 151$ мм. Длина ручки - 97 мм, ширина - 17-26 мм. Размеры навершия на ручке $-23 \times 39$ мм. Толщина диска - до 1,5 мм, ручки - до 2,5-5 мм, навершия - до 2,5 мм (рис. 5,1).

3. Бронзовый трехлопастный наконечник стрелы (у правого локтя) с выделенной втулкой, основание которой находится выше окончания граней. В основании втулки расположено отверстие размерами $4,5 \times 2$ мм, образовавшееся в результате дефекта литья. Длина наконечника - 26,5 мм. Длина втулки - 10 мм, диаметр - 4,3 мм (рис. 4,15).

4. Бронзовый трехлопастный наконечник стрелы (у левого запястья) с выделенной втулкой. В основании втулки расположено отверстие размерами $7 \times 2$ мм, образовавшееся в результате дефекта литья. Длина наконечника - 34 мм. Длина втулки - 12 мм, диаметр 4,5 мм (рис. 4,16).

5. Шесть бронзовых наконечников стрел у правой кисти:

- пять бронзовых трехлопастных наконечников с выделенной втулкой (два фрагментированы). Длина наконечников - от 28,6 до 37,1 мм. Длина втулок - от 9,5 до 13 мм, диаметр - от 4,3 до 5 мм (рис. 4,8-12). На втулках двух наконечников расположены отверстия размерами $8 \times 2$ и $9 \times 2,8$ мм, образовавшиеся в результате дефекта литья (рис. $4,8,10$ );

- бронзовый трехгранный наконечник стрелы со скрытой втулкой. Длина наконечника-22 мм, диаметр втулки - 3 мм (рис. 4,13).

6. Железный нож с утраченной деревянной рукоятью. Лезвие клиновидное в сечении, с нервюрой вдоль спинки с левой стороны. Черенок плоский, подпрямоугольный; рукоять крепилась при помощи двух заклепок. Длина сохранившейся части 87 мм. Ширина черенка - 10-15 мм, толщина -2-4 мм. Ширина лезвия - до 22 мм, толщина - до 4 мм. Толщина спинки - до 6 мм. Ширина нервюры - до 5 мм. Диаметр заклепок - около 3 мм (рис. 4,5).

7. Железная игла с обломанными ушком и острием. Длина фрагмента - 70 мм. Диаметр сечения - 2-3,5 мм (рис. 4,6).

8. Ожерелье состояло из 42 стеклянных бусин и одной стеклянной бисерины:

-41 асимметрично-сферическая бусина из голубого полупрозрачного (24 экз.) (рис. 4,148) и зеленоватого непрозрачного стекла (17 экз., из них 2 раздавлены) (рис. 4,14a). Высота бусин - 3,5-5 мм, диаметр - 4-6 мм. Диаметр конических отверстий - от 0,7-1,5 до 1,2-2 мм;

- поперечно-сжатая бусина из синего полупрозрачного стекла. Высота бусины 6,7 мм, диаметр $-8,7 \times 9$ мм. Диаметр отверстия - 3 мм (рис. 4,142);

- бисерина из красного непрозрачного стекла. Высота бисерины - 2 мм, диаметр - 3,3 мм. Диаметр отверстия - 1,2 мм (рис. 4,146). 
9. Пять поперечно-сжатых бусин (на правом локте), изготовленных из белого прозрачного стекла. Высота бусин - 4-4,4 мм, диаметр - 7,3-7,5 × 8 мм. Диаметр отверстий 3,3-4 мм (рис. 4,4).

10. Браслет из шести бисерин (на левом локте), изготовленных из желтовато-белого непрозрачного стекла. Высота бисерин - 1,51,8 мм, диаметр - 2,8-3,4 мм. Диаметр отверстий - 1,2-1,8 мм (рис. 4,3).

11. Каменная плита подтрапециевидной формы. Изготовлена из бурого песчаника, полностью обожжена. Лицевая поверхность вогнута до 7,5 мм и пришлифована, нижняя - не обработана. Размеры плиты - $360 \times 335$ мм. Толщина - 20-34 мм (рис. 6,2).

\section{Анализ данных}

Материалы из кургана 11 группы «Сад» у с. Глиное свидетельствуют, что он был сооружен для погребения рядовых общинников. Кольцевой ров ограничивал небольшую площадку (диаметром 8,5 м), на которой находились четыре захоронения. Примечательно, что в трех из них были погребены женщины, и еще в одном - маленький ребенок.

Планиграфические данные указывают, что основными были погребения 3 и 4, где женщины лежали головой в восточном направлении, а впускными - детское захоронение 1 и женское погребение 2, где погребенные были ориентированы головой в западный полукруг. Отметим при этом, что за все время исследований в окрестностях с. Глиное Слободзейского района скифских могил (сооруженных не позднее рубежа IV-III вв. до н.э.) погребенных с восточной ориентировкой было выявлено только четыре: Глиное/Сад, кург. 4, погр. 18 - захоронение ребенка 4 лет, головой на В [Синика и др., 2018б, с. 114, 116, рис. 3,7]; Глиное/Водовод, кург. 8, погр. 3 - захоронение женщины 20-30 лет, головой на ЮВ [Синика и др., 2018г, с. 236, рис. 2,1]; Глиное/Водовод, кург. 11, погр. 3 - захоронение женщины 35-40 лет [Łukasik, 2019b, p. 4], головой на ВЮВ; Глиное/Плавни, кург. 1, погр. 18 - захоронение ребенка, головой на СВ. Также крайне редка восточная ориентировка и в более позднее время. В частности, на скифском могильнике III-II вв. до н.э. у с. Глиное, где абсолютно доминируют меридиональные ориентировки, она зафиксирована всего в трех случаях: кург. 41, погр. 1 (взрослый, сопровождающее захоронение), кург. 52, погр. 1 (мужчина 20-35 лет, ориентировка стала результатом несоблюдения норм обряда), кург. 68, погр. 1 (женщина 20-35 лет, сопровождающее захоронение) [Тельнов и др., 2016, с. 271, 410, 752 , рис. $148,1,231,3,403]$. Кроме того, редкость подобной ориентировки (без учета северо-восточной и юго-восточной ориентировок, которые можно считать и меридиональными) уже отмечалась при анализе всех скифских погребений Дунайско-Днестровских степей [Синика, 2007a, с. 18; 2007б, с. 91].

Обычно восточная ориентировка связывается с греческим влиянием на скифский погребальный обряд [Ольховский, 1991, c. 155]. Данный тезис требует тщательной проверки материалов всех скифских погребений Северо-Западного Причерноморья, которая выходит за пределы настоящей работы. Здесь мы хотим подчеркнуть, что, судя по данным из памятников у с. Глиное, восточная ориентировка (без учета северо-восточной и юговосточной ориентировок) использовалась скифами исключительно редко и только при захоронении детей (Глиное/Сад, кург. 4, погр. 18, кург. 11, погр. 1) и женщин (Глиное/Сад, кург. 11, погр. 2; Глиное/Водовод, кург. 11, погр. 3; Глиное, кург. 41, погр. 1 (?), кург. 68, погр. 1).

Обращает на себя внимание и поза ребенка из погребения 1 кургана 11 Глиное/Сад скорченное положение на спине с разворотом на правый бок. За 125 лет изучения скифских погребальных памятников в Дунайско-Днестровских степях были изучены всего четыре захоронения с подобной позой (в скорченном положении на спине): Островное, кург. 3, погр. 1 на левобережье Нижнего Дуная [Алексеева, 1977, с. 47, табл. LV,1]; Глиное, кург. 70, погр. 1 [Тельнов и др., 2016, с. 431, 745, рис. 242,1$]$ и Глиное/Водовод, кург. 16, погр. 5 на левобережье Нижнего Днестра, погр. 10 грунтового могильника у с. Николаевка на левобережье Днестровского лимана [Мелюкова, 1975 , с. 74 , рис. 33,4$]$.

При тотальном доминировании вытянутого положения на спине на всем протяжении существования скифской культуры в СевероЗападном Причерноморье (вторая половина 
VII - II в. до н.э.) [Синика, 2007a, с. 18; 2007б, c. 90; Тельнов и др., 2016, с. 744-745] изредка фиксируются поза ничком [Тельнов и др., 2016, с. 745; Синика и др., 2019г, с. 283, 289-290, рис. $2,1,4,1,2]$ и скорченное положение на (правом и левом) боку и на спине [Субботин и др., 2017, c. 143]. При анализе данных из скифского могильника III-II вв. до н.э. у с. Глиное подчеркивалось, что «во всех комплексах, где была выявлена подобная поза погребенного, она являлась не следствием заранее запланированных обрядовых действий, а результатом определенных обстоятельств» [Тельнов и др., 2016, с. 745]. В полной мере это относится и к захоронению в погребении 1 кургана 11 Глиное/Сад, где тело ребенка из-за недостаточной длины погребальной камеры было невозможно уложить в вытянутом положении. Ранее подобная ситуация была отмечена в катакомбе погребения 5 кургана 67 могильника Глиное, длина камеры которой была меньше роста погребенного [Тельнов и др., 2016, с. 409, 745 , рис. 230,8$]$. Очевидно, эта «небрежность» при строительстве катакомбы 1 кургана 11 могильника Глиное/Сад была обусловлена низким социальным статусом ребенка, о чем также свидетельствует отсутствие инвентаря в захоронении. Все это в совокупности указывает, что данная могила была последней впущена в курган, после всех женских погребений.

Орудия труда из публикуемого кургана представлены ножами, пряслицами, иглой, лощилом и каменным изделием.

Железные ножи из захоронений погребения 2 кургана 11 (с роговой рукоятью) и погребения 4 кургана 11 (с деревянной рукоятью) относятся к наиболее распространенной категории орудий труда у скифов Северного Причерноморья. При этом обращает на себя внимание наличие утолщения (нервюры) на спинке из комплекса погребения 4 кургана 11 Глиное/Сад. Подобных ножей в настоящее время известно 12, и все они происходят из курганных групп, исследованных у с. Глиное Слободзейского района на левобережье Нижнего Днестра: Глиное/Сад, кург. 8, погр. 1 [Синика и др., 2018д, с. 82, рис. 3,2], кург. 11, погр. 4; Глиное/Водовод, кург. 7, погр. 2 и 4 [Синика и др., 2019а, с. 371, 376, рис. 4,4, 6,13], кург. 9, погр. 2 [Синика и др., 2019в, с. 10, рис. 3,8$]$, кург. 11, погр. 1, погр. 2, кург. 13, погр. 1, погр. 3, кург. 14, погр. 3, кург. 16, погр. 1, погр. 9. Размещение ножей вместе с костями от жертвенной пищи является одним из наиболее характерных элементов скифского погребального обряда [Синика, 2007б, с. 101; Тельнов и др., 2016, с. 800, рис. 419].

Пряслице из погребения 3 кургана 11 Глиное/Сад находилось в перемещенном состоянии, а в комплексе погребения 4 кургана 11 - у левого бедра женщины, маркируя размещение веретена в захоронении. Эти предметы, считающиеся типично женским инвентарем, хорошо известны у скифов Северо-Западного Причерноморья во второй половине VII - IV в. до н.э. [Синика, 2007a, с. 19], а позже - встречаются намного чаще [Тельнов и др., 2016, с. 803].

Железные иглы, аналогичные найденной в погребении 4 кургана 11, встречаются реже [Синика, 2007a, с. 19; Тельнов и др., 2016, c. 805]. При этом отмечено, что большинство погребений с иглами являлись женскими [Тельнов и др., 2016, с. 805]. Вызывает интерес место находки иглы. Она была положена под зеркало, которое, в свою очередь, находилось под телом женщины. К этому элементу погребального обряда (размещению предметов инвентаря под телом погребенных) мы еще вернемся при анализе находок зеркал из публикуемого кургана.

Лощило из ручки гераклейской амфоры, обнаруженное в насыпи кургана 11 могильника Глиное/Сад, практически не находит аналогий в скифских погребальных памятниках. Здесь можно упомянуть только «обломок амфорной ручки, превращенный в пестик» из погр. 1 кург. 1 (IV в. до н.э.) группы Степного кургана в Нижнем Поднепровье [Тереножкин и др., 1973, с. 180 , рис. 37,18$]$, а также лощило из насыпи кургана 41 (последняя четверть III - первая четверть II в. до н.э.) могильника у с. Глиное на левобережье Нижнего Днестра [Тельнов и др., 2016, с. 271, рис. 147,2]. В то же время в данном регионе, неподалеку от могильников Глиное и Глиное/Сад, лощила из ручек амфор широко представлены в материалах IV-II вв. до н.э. на поселениях Чобручи [Fidelschi, 2006, p. 28-29, pl. III,I] и Красное [Синика и др., 2012, с. 190, рис. 2,7].

Каменное изделие («курант») из насыпи кургана 11 Глиное/Сад в настоящее время 
является первой подобной находкой из скифских погребальных памятников Дунайско-Днестровских степей. При этом подобные изделия часто встречаются на погребальных и поселенческих памятниках эпохи энеолита, бронзового и раннего железного века лесостепной зоны Северного Причерноморья. Однако, за редким исключением [Никитенко, Лысенко, 2014, с. 334, 341-343], они не привлекают внимание исследователей.

Посуда из публикуемого кургана представлена только деревянной миской в погребении 3 кургана 11, от которой сохранились две железные обивки, обнаруженные вместе с костями животного в восточной части ямы. Скорее всего, жертвенная пища была положена в изголовье погребенной, как и в захоронениях кургана 11, погр. 2 и 4. Железные обивки подквадратной формы крепились на тулово деревянной миски при помощи шести гвоздейзаклепок. Кроме того, на двух противоположных сторонах пластин находятся по два дополнительных отверстия. По всей видимости, конструкция обивок предполагала различные способы их размещения на тулове сосуда, при котором могло быть использовано большее или меньшее количество отверстий для гвоздейзаклепок. При том, что в Северо-Западном Причерноморье в скифских погребениях известны различные железные скрепы и заклепки от деревянных мисок [Тельнов и др., 2016, c. 830-831, рис. $428,1-6]$, обивки подобной формы найдены впервые.

Украшения из кургана Глиное/Сад 11 представлены парой серег (погр. 3 кург. 11), ожерельями из бусин (кург. 11, погр. 2 и 4), браслетом из бусин (погр. 2 кург. 11), двумя «локтевыми браслетами» (погр. 4 кург. 11), а также бусиной и двумя амфоровидными подвесками, которые могли входить в состав как ожерелья, так и браслетов (погр. 3 кург. 11).

Серьги из погребения 3 кургана 11 с коническими утолщениями на одном из окончаний являются довольно редкими находками в Северо-Западном Причерноморье. В.Г. Петренко отмечает, что такие серьги появляются в скифских погребениях не ранее IV в. до н.э., при этом только в памятниках Поднестровья. Однако исследователь указывает, что подобные изделия достаточно хорошо известны в памятниках VI-V вв. до н.э. Румынии, Болгарии,
Венгрии и Боснии, и связывает их появление в Северо-Западном Причерноморье с фракийским влиянием [Петренко, 1978, с. 34-35]. Об этом, например, свидетельствуют находки трех аналогичных изделий (одного золотого кольца и двух серебряных серег) в составе гетского клада из с. Матеуцы [Băţ et al., 2019, p. 311, fig. 15] на правобережье Среднего Днестра.

На левобережье Нижнего Днестра серьги, оба окончания которых оформлены в виде конических утолщений, обнаружены в скифских курганах 1 у с. Суклея и 345 у с. Чобручи [Мелюкова, 1962, с. 151, табл. 10,2,3], а также в погребении 5 могильника Николаевка I [Дзис-Райко, 1965, с. 66, рис. 4,10]. Серьги с коническими шишечками на окончаниях обнаружены в комплексах кург. 19, погр. 2 (пара серебряных серег), кург. 57, погр. 1 (одна серебряная серьга), кург. 109, погр. 1 (пара серебряных серег) скифского могильника IIIII вв. до н.э. у с. Глиное [Синика и др., 2016, с. 112, № 128; Тельнов и др., 2016, с. 165, 355, $642-643,975$, рис. $73,11,200,7,362,7,8]$. Однако в 1984 г. такие украшения были найдены и на левобережье Нижнего Дуная - в погребении 1 кургана 23 (бронзовое височное кольцо) и погребении 1 кургана 24 (серебряная серьга) могильника Мреснота Могила [Гудкова и др., 1985, с. 103-104, рис. 61,6, 62,3]. Дата перечисленных комплексов укладывается в рамки последней четверти IV - II в. до н.э. Кроме того, в 2017 г. бронзовая серьга с одним окончанием в виде конического утолщения, очевидно, использованная вторично в качестве кольца, была обнаружена в ограбленном погребении 1 кургана 5 могильника Глиное/Сад, относящемуся ко второй половине IV в. до н.э. [Sinika et al., 2017, p. 159, 163, fig. 2,4; Синика, Тельнов, 2018в, с. 164-165, рис. 1,8]. В 2018 г. при исследовании непотревоженного парного захоронения конца третьей четверти IV в. до н.э. Глиное/Водовод, кург. 16, погр. 4 была выявлена пара аналогичных бронзовых серег.

Ожерелья из стеклянных бусин в погребениях 2 и 4 кургана 11, а также браслет из бусин на правом запястье из погребения 4 относятся к самой многочисленной разновидности украшений из скифских захоронений Северного Причерноморья. При этом ожерелья, за редким исключением, встречены только в женских и детских захороне- 
ниях, а браслеты - и в мужских [Тельнов и др., 2016, с. 858, 863].

В то же время находки мелких украшений (бусин, подвесок и др.), составлявших так называемые «локтевые браслеты», как это отмечено на правом и левом локте женщины в захоронении 4 кургана 11 Глиное/Сад, крайне редки в скифских комплексах Северо-Западного Причерноморья IV в. до н.э. До настоящего времени два подобных браслета были найдены только в кургане Глиное/Сад 7, сооруженном в последней четверти IV в. до н.э. В одном из детских захоронений кургана (кург. 7 погр. 1) возле левого локтя ребенка находились 15 стеклянных бусин, а в другом (кург. 7 погр. 4) - шесть костяных пронизей возле правого локтя [Синика и др., 2018в, с. 128-129, 135 , рис. $2,1,4,5]$. В последующее время «локтевые браслеты» получат большее распространение, о чем свидетельствуют их находки в 21 захоронении (13 женских, пяти мужских и трех детских) скифского могильника III-II вв. у с. Глиное. По всей видимости, «локтевые браслеты» из бусин (правый локоть) и из бисерин (левый локоть) в погребении 4 кургана 11 группы «Сад» нашивались на рукава одежды в области локтя, а костяные пронизи из захоронения 4 кургана 7 группы «Сад» были надеты на нить, которая нашивалась на рукав [Тельнов и др., 2016, с. 968-871, табл. 24; Синика, Тельнов, 2018б, с. 257].

Присутствие бисера в захоронениях Глиное/Сад, кург. 11, погр. 2 (четыре бисерины в составе ожерелья) и кург. 11, погр. 4 (шесть бисерин в составе «браслета» на левом локте, одна бисерина в составе ожерелья) группы «Водовод» вызывает особый интерес. Подобные украшения также немногочисленны в скифских комплексах Северо-Западного Причерноморья V-IV в. до н.э. Они известны только в 14 погребениях: кург. 11, погр. 3 у с. Нагорное [Андрух, Суничук, 1987, с. 43, рис. 4,11], кург. 5, погр. 1 могильника Кугурлуй [Гудкова, Суничук, 1985, с. 31, табл. 68,9,10], кург. 8, погр. 1 и кург. 15, погр. 1 могильника Мреснота Могила [Гудкова и др., 1985, с. 83, 91, рис. 50,11, 55,6] на левобережье Нижнего Дуная, кург. 3, погр. 1 могильника Хаджидер I [Субботин и др., 1992, с. 23, рис. 20,17] в Дунайско-Днестровском междуречье, кург. 4, погр. 6 у с. Никольское [Агульников, Сава,
2004, с. 44], Глиное/Сад, кург. 6, погр. 1 [Sinika et al., 2017, p. 161, 165-166, fig. 3,5b-o], Глиное/Водовод, кург. 7, погр. 3, кург. 7, погр. 4 [Синика и др., 2019а, с. 374, 377, 385-386, рис. 5,23, 7,3в], кург. 9, погр. 2 [Синика и др., 2019в, с. 9, рис. 3, 7,14], кург. 10, погр. 3 [Синика и др., 2019б, рис. 6,1ж], кург. 13, погр. 2, кург. 16, погр. 5 на левобережье Нижнего Днестра и кург. 5, погр. 1 у с. Неделково [Редина, 1999, с. 77] в Днестро-Бугском междуречье. В то же время на скифском могильнике IIIII вв. до н.э. у с. Глиное отмечено тотальное доминирование бисера в ожерельях, а также его присутствие в других составных украшениях, связанных исключительно с женскими и детскими костяками и не встреченных на мужских [Тельнов и др., 2016, с. 850, 853, 858, 868, 874, 876-877, 884].

Предметы туалета из кургана 11 группы «Сад» представлены только зеркалами. Они были положены во все три захоронения взрослых в кургане 11 (погр. 2, 3, 4), причем все они принадлежали женщинам. Подобный случай впервые отмечен в Северо-Западном Причерноморье.

Зеркала из погребений 2 и 4 кургана 11 Глиное/Сад идентичны. Это бронзовые изделия с круглым диском и боковой ручкой, вырезанные из одного листа. Ручки обоих зеркал сделаны в виде вытянутой трапеции, окончание которой оформлено в виде овального навершия. Девять подобных зеркал обнаружены в скифских комплексах Северо-Западного Причерноморья V-IV вв. до н.э. На левобережье Нижнего Дуная - в погр. 3 кург. 5 Котловина I [Фокеев, 1991, с. 16, рис. 25,8] третьей четверти IV в. до н.э., в Дунайско-Днестровском междуречье - в захоронениях Балабаны, кург. 6, погр. 2 [Чеботаренко и др., 1989 , с. 34 , рис. 12,2] и Кочковатое, кург. 48, погр. 2 [Ванчугов и др., 1992, с. 51, рис. 15,2] третьей четверти IV в. до н.э., на правобережье Нижнего Днестра - в погр. 6 кург. 1 Пуркары [Яровой, 1990, с. 51-52, рис. 21,2] середины IV в. до н.э., на левобережье Нижнего Днестра-в захоронениях Дубоссары, кург. 18, погр. 1 второй четверти IV в. до н.э. [Кетрару и др., 2014, с. 85, 213-215, рис. 70,9], Никольское, кург. 14, погр. 1 [Агульников, Сава, 2004, с. 124 , рис. 62,2$]$ рубежа V-IV вв. до н.э., Глиное/Водовод, кург. 7, погр. 4 [Синика и др., 
2019a, с. 376, 386, рис. 7,1] рубежа IV-III вв. до н.э. и Николаевка-23 [Мелюкова, 1975, с. 82, рис. 49,5] конца первой - начала второй четверти IV в. до н.э., в Днестро-Бугском междуречье - в погребении 1 кургана 9 Неделково [Редина, 1999 , с. 80 , рис. 3,7$]$ третьей четверти IV в. до н.э.

Крайне примечательной деталью обряда является размещение зеркал в погребениях 2 и 4 кургана 11 Глиное/Сад. Они были положены под тела погребенных, при этом в погребении 4 рукоять зеркала была отломана в древности, а под его диском, как отмечалось выше, находилась игла.

Очевидно, здесь мы имеем дело с элементом погребального обряда (размещение инвентаря в могиле под телом умершего), которому ранее практически не придавалось значения. В 2011 г. на него впервые обратили внимание Ю.В. Болтрик и Е.Е. Фиалко в статье, посвященной лежавшему под спиной зеркалу из погребения служанки в Центральной гробнице кургана Огуз [Болтрик, Фиалко, 2011, c. 92]. Спустя восемь лет вывод исследователей о том, что такое размещение зеркал свидетельствует о статусе зависимого лица, был подвергнут абсолютно обоснованной критике со стороны С.В. Полина и М.Н. Дараган. Данные авторы сформулировали заключение, с которым нельзя не согласиться: «Тезис о том, что размещение зеркала под телом погребенной является признаком зависимого статуса погребенной женщины, является полностью надуманным, подкрепляется ошибочно изложенными фактами и абсолютно опровергается фактом находки зеркала под левой лопаткой "царицы" в боковой гробнице Толстой Могилы» [Полин, Дараган, 2019, с. 212].

В 2019 г. в публикации кургана 7 группы «Водовод», где были найдены серебряное кольцо, положенное под спину ребенка в катакомбе погребения 5 кургана 7, и зеркало, положенное слева под нижнюю часть грудной клетки женщины из погребения 4 кургана 7 Глиное/Водовод, мы обратили внимание на этот элемент обряда, но специальный анализ не проводился [Синика и др., 2019а, с. 384, 386].

Помимо публикуемых комплексов, помещение зеркал под тело зафиксировано в Северо-Западном Причерноморье еще в шести случаях. Это погребение 5 кургана 5 Глиное/
Водовод (диск под правым плечом) [Синика, Тельнов, 2017б, с. 7, рис. 1,1; 2018a, с. 138, рис. 3,4], упомянутый выше комплекс Глиное/ Водовод, кург. 7, погр. 4, а также захоронения Глиное/Водовод, кург. 11, погр. 2 (диск под правым плечом), кург. 14, погр. 3 (ручка и часть диска под правым плечом), Пуркары, кург. 1, погр. 6 на правобережье Нижнего Днестра [Яровой, 1990, с. 51, рис. 21,1] и Неделково, кург. 9, погр. 1 в Днестро-Бугском междуречье [Редина, 1999, с. 77, рис. 3,2]. Кроме того, совсем недавно была опубликована сводка из 49 скифских захоронений Северного Причерноморья второй половины $\mathrm{V}$ - IV в. до н.э., где зеркала были положены под тела погребенных [Полин, Дараган, 2019, с. 210, № 106-154]. Эта работа, доступная заинтересованному специалисту, позволяет нам избежать их повторного перечисления. Отметим только, что в выборку не вошли опубликованные ранее погребения Глиное/Водовод, кург. 5, погр. 5, Неделково, кург. 9, погр. 1 и Калиновка II, кург. 7, погр. 1 [Никитин, 2018, с. 108, рис. 47,4], а катакомбы Мамай-Гора, кург. 4, погр. 9 и Чкаловка V были включены в кластер 2 («зеркала с правой стороны скелета») [Полин, Дараган, 2019 , с. 209, № 46, 59], хотя в данных захоронениях зеркала лежали соответственно под правым локтем женщины [Андрух, Тощев, 1999, c. 36] и под правой кистью [Ковалева, 1999, c. 131, pис. 2,2], то есть, по нашему мнению, под телом.

По всей видимости, обряд размещения зеркал под телом погребенного (Глиное/Сад, кург. 11, погр. 2, 4), как и их преднамеренная поломка и порча (Глиное/Сад, кург. 11, погр. 4), связан с анимистическими представлениями, согласно которым зеркало является вместилищем души [Смирнов, 1964, с. 103, 249; Бессонова, 1983, с. 102-103; Медведев, 1990, с. 185; Марченко, 1996, с. 109; Раевский, 2006, с. 124]. Именно поэтому мы считаем, что зеркала клали в могилы в футлярах или под тело, ограждая таким образом живых от души мертвого. В тех комплексах, где зеркала не были в футлярах (или футляры не были зафиксированы) и не лежали под телом, они могли быть накрыты подстилкой, частями одежды погребенного либо другими несохранившимися легкими органическими материалами. При этом семантика обряда была такой же (предотвращение 
воздействия души умершего на живых соплеменников), что и в случаях, когда зеркала клали в футляры или под тело.

Недавно была высказана и иная интерпретация обряда помещения зеркала под тело умершего, в качестве «особого ритуала, когда зеркало выступает в роли некоего “проводника”, открывающего “портал” в потусторонний мир хтонических сил» [Полин, Дараган, 2019 , с. 211]. Гораздо сложнее при этом интерпретировать иные предметы (кольцо - Глиное/Водовод, кург. 7, погр. 5; игла - Глиное/Сад, кург. 11, погр. 4), положенные под тело погребенного. Однако со временем при тщательной систематизации подобных случаев гипотезы у исследователей, несомненно, появятся.

Нельзя не остановиться и на обряде порчи зеркал, поскольку ручка находки из погребения 4 кургана 11 Глиное/Сад была отломана в нижней части. О том, что ее путем многократного сгибания отделяли преднамеренно, свидетельствует тот факт, что в месте слома и на прилегающих участках толщина ручки меньше (2,5 мм), чем возле диска и возле навершия (4 мм). Такой обычай (поломки зеркал) до настоящего времени достоверно был зафиксирован только в двух скифских погребениях Северного Причерноморья, совершенных в последней трети V в. до н.э. (Ново-Васильевка, кург. 17, погр. 1 и 3 [Полин, Дараган, 2019, с. 213, № 4, 5] в Нижнем Поднепровье), и в десяти катакомбах могильника III-II вв. до н.э. у с. Глиное Слободзейского района на левобережье Нижнего Днестра [Тельнов, Синика, 2014, с. 240; Тельнов и др., 2016, с. 895].

Предметы культа из кургана 11 группы Сад представлены подвеской из коренного зуба собаки в погребении 3, а также каменной плитой - в погребении 4.

Подвески из зубов (преимущественно, клыков) собаки весьма немногочисленны в скифских захоронениях на левобережье Нижнего Днестра: Глиное/Водовод, кург. 5, погр. 3 (один клык с отверстием для подвешивания в составе ожерелья ребенка) [Синика, Тельнов, 2018a, с. 134-135, рис. 2,11], кург. 7, погр. 3 (два клыка, один с отверстием для подвешивания, в перемещенном состоянии) [Синика и др., 2019а, с. 374, 386, рис. 5,8,9], кург. 14, погр. 3 (коренной зуб под правым крылом таза женщины), кург. 16, погр. 4 (два клыка в составе ожерелья ребенка, на одном сохранилось отверстие для подвешивания), Глиное/ Сад, кург. 8, погр. 1 (три клыка в составе ожерелья ребенка, на одном сохранилось отверстие для подвешивания) [Синика и др., 2018д, с. 82,89 , рис. 2,7]. Помимо этого, в СевероЗападном Причерноморье такие находки известны еще в трех комплексах. На левобережье Нижнего Дуная это Градешка, кург. 7а, погр. 1 (три клыка с отверстиями для подвешивания в составе скопления украшений справа в ногах ребенка) [Гудкова, Суничук, 1985, c. 71, 73, табл. 132,1,2] и Кугурлуй, кург. 31, погр. 1 (клык с отверстием для подвешивания на груди женщины) [Гудкова, Суничук, 1985, с. 65]. В Дунайско-Днестровском междуречье клык с отверстием для подвешивания найден в ограбленном захоронении Тараклия, кург. 19, погр. 3 [Савва и др., 1985, с. 6869 , рис. 95,4]. Как показывает анализ, в большинстве случаев, где установлено изначальное размещение зубов собаки, они входили в состав ожерелий женщин и детей. Вполне вероятно, что и подвеска из коренного зуба собаки из погребения 3 кургана 11 Глиное/Сад (женщина) также являлась частью ожерелья.

Отметим, что каменные плиты представляют собой типичный инвентарь как мужских, так и женских скифских погребений. В частности, только в непосредственной близости от кургана 11 группы «Сад» они были найдены в 39 комплексах на левобережье Нижнего Днестра: Глиное/Водовод, кург. 2, погр. 12 [Синика, Тельнов, 2017в, с. 143, 145, рис. 4,6], кург. 9, погр. 2 [Синика и др., 2019в, с. 10-11, рис. 3,2], кург. 11, погр. 1, кург. 14, погр. 3; Глиное/Сад, кург. 9 (во рву) [Синика и др., 2018а, с. 167, 170 , рис. 1,3], кург. 11, погр. 4, кург. 13, погр. 3; Глиное/Рыбхоз, кург. 2, погр. 1; Глиное, кург. 11, погр. 1, кург. 13, погр. 1, кург. 19, погр. 1, кург. 19, погр. 2, кург. 23, погр. 1, кург. 31, погр. 1, кург. 32, погр. 1, кург. 35, погр. 1, кург. 38, погр. 1, кург. 38, погр. 3, кург. 51, погр. 1, кург. 54, погр. 3, кург. 55, погр. 1, кург. 60, погр. 1, кург. 61, погр. 1, кург. 69, погр. 2, кург. 74, погр. 2, кург. 78, погр. 3, кург. 79, погр. 1, кург. 81, погр. 1, кург. 81, погр. 3, кург. 82, погр. 1, кург. 86, погр. 1, кург. 88, погр. 1, кург. 89, погр. 3, кург. 95, погр. 1, кург. 99, погр. 1, кург. 100, погр. 1, кург. 104, 
погр. 1, кург. 106, погр. 1, кург. 107, погр. 3 [Тельнов и др., 2016, с. 918-919]; кург. $116-$ во рву [Синика, Тельнов, 2018б, с. 224, 246247 , рис. 2,4$]$. Однако каменная плита из захоронения Глиное/Сад, кург. 11, погр. 4, в отличие от всех остальных подобных находок, была полностью обожжена, а затем положена в могилу. Весьма вероятно, что этот элемент обряда коррелирует с помещением в данный комплекс под тело погребенной зеркала с отломанной в древности рукоятью, а также иглы под диск зеркала.

Предметы вооружения из кургана 11 группы «Сад» немногочисленны и представлены только бронзовыми наконечниками стрел. В ограбленном погребении 3 кургана 11 сохранился лишь один наконечник, а в непотревоженном погребении 4 - восемь наконечников. Обращает на себя внимание размещение последних. Один наконечник был найден у правого локтя и находился острием вниз, второй (также острием вниз) - у левой кисти.

Отметим, что нестандартное размещение наконечников стрел было неоднократно зафиксировано в скифских погребальных комплексах на левобережье Нижнего Днестра. Например, среди детских погребений можно указать следующие комплексы: Глиное/Водовод, кург. 6, погр. 1 [Синика и др., 2018е, с. 73, 76 , рис. 2,2,4], кург. 7, погр. 5 [Синика и др., 2019 a, с. $379,382,387$, рис. $8,2,6,7]$, кург. 8 , погр. 2 и 4 [Синика и др., 2018г, с. 236, 238, 241-242, рис. 1,6,8,9,11,3,1,3], кург. 13, погр. 1; Глиное, кург. 12, погр. 2 [Тельнов и др., 2016, c. 121], кург. 116, погр. 1 [Синика, Тельнов, 20186 , с. 229 , рис. 5,5$]$. Перечисленные захоронения свидетельствуют о существовании у скифов нормы обряда, регламентировавшей размещение стрел поверх тел детей, возле них и на перекрытиях ям. Однако совершенно очевидно, что эти микроэлементы погребального ритуала не фиксировали принадлежность детей к воинскому сословию.

В полной мере это относится и к погребениям взрослых, где отмечено нестандартное размещение наконечников стрел, как в погребении 4 кургана 11 Глиное/Сад. Наконечники стрел, обнаруженные в вертикальном положении у правого локтя и у левого запястья женщины, по всей видимости, упали с перекрытия, поскольку зафиксированы они на
12 см выше дна ямы. Подобная ситуация была отмечена и в комплексе Глиное/Водовод, курган 15, погребение 5, где единственный наконечник стрелы был найден острием вниз между правыми плечевым суставом и лопаткой погребенного возрастом более 50 лет [ ukasik, 2019b, p. 9], при этом на его костях нет следов окисления бронзы. Данные погребения (как и другие, где на перекрытии лежали иные предметы), очевидно, отражают обычай помещения напутственных даров на перекрытие погребального сооружения [Синика и др., 2019г, с. 283-284, 292, рис. 2,1,3].

Две стрелы были воткнуты в дно погребальной камеры (у ее входа и у противоположной стенки) катакомбы 2 кургана 11 Глиное/Водовод, где был похоронен мужчина 3550 лет [Łukasik, 2019b, p. 4]. Одна стрела была воткнута в дно ямы у левого плеча женщины 15-20 лет в погребении 3 кургана 10 Глиное/ Водовод [tukasik, 2019b, p. 3]. Возможно, они фиксировали циновку и/или края погребального савана.

В погребении 3 кургана 10 Глиное/Водовод еще три наконечника лежали горизонтально - один справа и два слева у таза. Один наконечник стрелы найден на правом локте мужчины 35-40 лет [tukasik, 2019b, p. 6] в комплексе Глиное/Водовод, кург. 13, погр. 1. В погребении 3 кургана 13 Глиное/Водовод, где был захоронен мужчина 35-40 лет [ tukasik, 2019b, p. 8], три наконечника стрел зафиксированы в горизонтальном положении: один - у правого плеча, второй - у левого крыла таза, третий - ниже правого тазобедренного сустава, с внутренней стороны бедренной кости. В могиле 11 кургана 16 Глиное/Водовод при погребенном возрастом 20-30 лет (пол не определен) [Łukasik, 2019b, p. 15] пять наконечников лежали горизонтально: два, остриями обращенные друг к другу, с внешней стороны левой бедренной кости; еще один - с внутренней стороны левой бедренной кости, острием к ней; один - поверх левого локтя; один - у правого крыла таза, острием в сторону ног. Все эти наконечники, зафиксированные in situ, скорее всего, указывают, что стрелы были положены сверху на тела погребенных. В катакомбе погребения 1 кургана 6 могильника Нагорное в Нижнем Поднепровье две стрелы были положены вдоль правого и левого бедра «взрос- 
лой женщины» наконечниками в сторону головы [Мозолевский, 1973, с. 196-197, рис. 10].

Перечисленные случаи свидетельствуют, что отдельные находки предметов вооружения (в нашем случае, наконечников стрел) не являются достаточным основанием определения принадлежности погребенного к воинскому сословию. Например, в захоронениях Глиное/Водовод, кург. 11, погр. 2 и кург. 13, погр. 3 были найдены колчанные наборы (по одному в каждом) и копья (по паре в каждом), а в комплексах Глиное/Водовод, кург. 10, погр. 3 [Синика и др., 2019б, рис. 4,1] и кург. 13, погр. 1 - по одному колчанному набору, и именно они, в отличие от отдельных наконечников стрел (воткнутых в дно камеры или лежавших поверх тела), указывают на воинскую принадлежность погребенных.

Подобная ситуация была зафиксирована и в захоронении Глиное/Сад, кург. 11, погр. 4. Напомним, оно не было потревожено грабителями, и, помимо двух «отдельных» наконечников стрел у правого локтя и у левого запястья, справа от таза женщины были найдены шесть наконечников стрел. Они компактно располагались у северной стенки ямы, в 12 см выше ее дна. По всей видимости, это колчанный набор, упавший с перекрытия ямы либо из колчана, повешенного на ее стенку. Второй вариант мы не исключаем, поскольку подобный обычай (подвешивание колчана к стенке погребального сооружения) был достоверно зафиксирован в катакомбе погребения 3 кургана 13 Глиное/Сад, где в изголовье погребенного находился колчанный набор, а также железный крюк и железный «колышек» для фиксации крюка в стене погребальной камеры. В другой катакомбе (Глиное/Сад, кург. 12, погр. 3) отдельно лежавшие у левого плеча мужчины шесть наконечников стрел могли быть подвешены к стенке или к своду камеры, поскольку колчанный набор (94 наконечника) был зафиксирован слева от таза погребенного [Синика и др., 2020, рис. 2,1].

В любом случае, где бы ни находился изначально колчанный набор из погребения 4 кургана 11 Глиное/Сад, данный комплекс можно рассматривать как захоронение скифской «воительницы». Согласно определению антрополога, в нем была погребена женщина возрастом 20-35 лет [Łukasik, 2019a, p. 3]. Ee co- провождал типично женский инвентарь (зеркало, пряслице, ожерелье), а также колчанный набор, состоявший из шести стрел. Аналогичная ситуация зафиксирована в захоронении Глиное/Водовод, кург. 10, погр. 3: несмотря на то что антропологом ввиду возраста (1520 лет) пол погребенного не был определен [Łukasik, 2019b, p. 3], о том, что это женщина, свидетельствует инвентарь - два керамических пряслица за головой погребенной и пара бронзовых лировидных подвесок - у висков. Кроме того, у левого бедра в колчане лежали 20 наконечников стрел [Синика и др., 2019б, рис. 4,1]. В захоронении женщины 35-40 лет Глиное/Водовод, кург. 11, погр. 3 [Łukasik, 2019b, p. 4], помимо ожерелья на шее, был зафиксирован колчанный набор из 12 наконечников стрел. В могиле 5 кургана 16 Глиное/Водовод была погребена женщина (?) 40-50 лет [Łukasik, 2019b, p. 12] с парными серьгами, ожерельем на шее, одним пряслицем и колчанным набором из десяти стрел.

\section{Датировка кургана}

При определении времени сооружения кургана 11 Глиное/Сад необходимо учитывать несколько важных обстоятельств. Во-первых, это одновременное устройство двух женских захоронений (погр. 3, 4), где погребенные лежали головой на В. Эти могилы располагались в центральной части площадки, окруженной кольцевым рвом. Женское (погр. 2) и детское (погр. 1) захоронения были впущены в насыпь. Позднейшим из них, судя по глубине, отсутствию инвентаря и небрежности соблюдения обрядовых норм (скорченное положение на спине с разворотом на правый бок), было захоронение ребенка. Во-вторых, инвентарь из женских могил едва ли не идентичен: бронзовые зеркала (погр. 2 и 4), пирамидальные стеклянные подвески (погр. 2 и 3); трехлопастные наконечники стрел (погр. 3 и 4). С учетом изложенного очевидно, что датировка всех погребений кургана, а значит, и время его сооружения, укладывается в относительно небольшой интервал времени.

Отсутствие керамических импортов, за исключением невыразительной ручки гераклейской амфоры в насыпи, несколько осложняет получение узкой даты комплекса, однако не 
означает невозможность ее определения. Для решения этой задачи будут использованы накопленные данные о времени бытования бронзовых зеркал из погребений 2 и 4 кургана 11 Глиное/Сад, а также наконечников стрел из погребений 3 и 4 кургана 11 Глиное/Сад.

Несомненно, наиболее ранним комплексом с зеркалом, аналогичным двум найденным в кургане 11 Глиное/Сад (цельные, с круглым диском и ручкой, окончание которой оформлено в виде овального/круглого навершия), как указано выше, является Никольское, кург. 14, погр. 1 рубежа V-IV вв. до н.э., фиксируя появление подобных изделий в Северном Причерноморье, а наиболее поздним Глиное/Водовод, кург. 7, погр. 4, где такое зеркало попало в захоронение на рубеже IV-III вв. до н.э. Однако большинство аналогичных бронзовых зеркал (7) происходит из погребений второй - третьей четверти IV в. до н.э. (Балабаны, кург. 6, погр. 2; Дубоссары, кург. 18, погр. 1 ; Котловина I, кург. 5, погр. 3; Кочковатое, кург. 48, погр. 2; Неделково, кург. 9, погр. 1; Николаевка, кург. 23; Пуркары, кург. 1, погр. 6), при этом пять из них, за исключением находок из захоронений Дубоссары, кург. 18, погр. 1 и Николаевка, кург. 23, найдены в могилах третьей четверти указанного столетия.

Наконечники стрел представлены разными типами. Один из них (Глиное/Сад, кург. 11, погр. 4, у правого локтя) наиболее ранний (базисный). Подобные наконечники стрел, появившись у скифов Северо-Западного Причерноморья в первой половине V в. до н.э., получают наибольшее распространение во второй половине указанного столетия [Синика, 2007б, c. 168-169]. Большинство наконечников (Глиное/Сад, кург. 11, погр. 4: один - у левого запястья, четыре - в колчанном наборе; Глиное/Сад, кург. 11, погр. 3) опорновтульчатые. Такие наконечники в скифских могилах Дунайско-Днестровских степей появляются во второй половине $\mathrm{V}$ в. до н.э., однако чаще всего встречаются в комплексах IV - начала III в. до н.э. [Синика, 2007б, с. 169-172]. Наконец, трехгранные наконечники стрел со скрытой втулкой получают самое широкое распространение только во второй половине IV в. до н.э. [Мелюкова, 1964, с. 25; Синика и др., 2013 , с. 128]. Один такой наконечник, найденный в колчане в погребении 4 кургана 11 Гли-
ное/Сад, является наиболее поздним из всех обнаруженных в захоронениях кургана.

С учетом изложенного мы датируем все захоронения кургана 11 Глиное/Сад второй половиной (предпочтительно третьей четвертью) IV в. до н.э.

\section{Современное «мифотворчество» о скифских «амазонках»}

Публикация женского комплекса с колчанным набором из погребения 4 кургана 11 Глиное/Сад, а также исследование еще трех аналогичных комплексов - Глиное/Водовод, кург. 10, погр. 3 [Синика и др., 2019б], кург. 11, погр. 3 и кург. 16, погр. 5 на левобережье Нижнего Днестра - заставляет нас рассмотреть вопрос о захоронениях скифских «амазонок». На этот счет существует столь обширная научная литература (данные письменных источников об амазонках, их изображения в античной вазописи и торевтике, состав вооружения из женских захоронений и т. д.), что одно ее перечисление, не говоря об анализе, выходит далеко за пределы настоящей работы.

Наиболее важна для нас проблема отнесения тех или иных погребальных комплексов, в которых сочетались предметы вооружения и инвентарь, являющийся/считающийся женским, к захоронениям «амазонок».

Здесь мы впервые обратимся к цитате, вынесенной в эпиграф нашей работы. Семь лет назад двое из ее авторов, рассматривая совершенно другую проблему, заметили, что «ошибочные утверждения, тем более высказанные неоднократно, никем не оспоренные и не оспариваемые, со временем "по умолчанию" приобретают видимость непреложных истин. Такие "истины" в дальнейшем становятся отправной точкой тех или иных научных построений, фундамента которых просто не существует» [Тельнов, Синика, 2013, с. 306]. В полной мере это утверждение относится и к совершенно надуманной проблеме скифских «амазонок» в Северном Причерноморье.

В последнее десятилетие она актуализировалась, поскольку в специальных статьях, назвать которые научными можно с трудом, внезапно «возникли», а точнее, «были созданы» многие десятки захоронений скифских «амазонок», «женщин-воительниц», «жен- 
щин-воинов». При этом словосочетание «скифские амазонки», как утверждается, «стало обычным и частоупотребляемым» [Фиалко, 2015, с. 46].

Чтобы не быть голословными, перейдем к анализу некоторых скифских комплексов, объявленных Е.Е. Фиалко принадлежащими скифским «амазонкам» без должных или вообще безо всяких оснований.

Погребение 4 в кургане 13 могильника Буторы I на левобережье Нижнего Днестра было причислено к захоронениям «амазонок» на основании находок, среди прочего инвентаря, фрагментов костяного веретена, двух пряслиц и трех наконечников стрел [Фиалко, 2015 , с. 62 , рис. $27, A, 28]$. При этом исследователя не смутили практически полное ограбление захоронения и отсутствие антропологических определений. В расчет также не была принята возможность, что погребальный комплекс мог быть парным, и в этом случае веретено и пряслица принадлежали женщине, а предметы вооружения - мужчине. Однако этот комплекс, как и многие другие, был столь же безосновательно, как и безоговорочно, включен в обширный список захоронений «амазонок».

Такой «методический прием» применялся Е.Е. Фиалко неоднократно.

Так, ограбленное погребение 2 кургана 2 Дубоссары на левобережье Нижнего Днестра, содержавшее кости одного индивидуума, было отнесено к «сонму амазонок» на основании находок в нем четырех наконечников стрел и 31 бусины [Фиалко, 2015, с. 63, рис. 29,Б]. Здесь нам остается предположить, что основанием для такого заключения стал рисунок в публикации, где все бусины были изображены надетыми на одну нить [Кетрару и др., 2014, с. 45, рис. 34,3$]$. О том, что они могли составлять браслеты на запястьях, локтевые «браслеты» и иные украшения, которые встречаются в мужских захоронениях [Тельнов и др., 2016, c. 884-885], но не женское ожерелье, автор, очевидно, даже не задумывался.

Совершенно «феноменальными» выглядят две ограбленные могилы «амазонок» в Среднем Подонье, для которых нет антропологических определений. Одним из них является «захоронение ребенка - девочки» в кургане 21 у с. Дуровка, где из вещей сохрани- лись два наконечника стрел, лепная чашка и восемь стеклянных бусин [Фиалко, 2015, с. 66, рис. 33,5$]$, другим - погребение 5 в кургане 33 Мастюгино, в гробнице которого найдены наконечник стрелы, серьга, бусина и раковина каури [Фиалко, 2015, с. 66, рис. 33,A]. Даже если не рассматривать версию возможного парного захоронения, остается только догадываться, какие из сохранившихся предметов в указанных могилах можно считать исключительно женским инвентарем. По всей видимости, по мнению Е.Е. Фиалко, таковыми являются любая бусина и любая серьга. О бусинах в мужских захоронениях мы уже высказались выше. Относительно серег заметим, что и они изредка (по одной, у одного из висков) встречаются у мужчин [Тельнов и др., 2016, c. 882], с чем ранее соглашалась и сама Е.Е. Фиалко [Фиалко, 1991, с. 11].

В заполнении ограбленной катакомбы 3 кургана 5 могильника Мамай-Гора в Нижнем Поднепровье сохранились одна бусина, восемь наконечников стрел, фрагменты лепных сосудов, железных изделий, два камня, бронзовые бляшки. Антрополог установила, что человеческие кости принадлежали женщине 30 35 лет [Фиалко, 2010, с. 188, рис. 1,7]. В этом случае связь женского костяка с наконечниками стрел совершенно не очевидна; они могли входить и в колчанный набор мужчины, костяк которого грабителями был вынесен из погребальной камеры.

Такой подход к созданию выборки погребений скифских «амазонок» (с включением в нее ограбленных захоронений, как правило, без антропологических определений костяков) не только вызывает неприятие, поскольку не выдерживает никакой критики, но и удивление, поскольку сама Е.Е. Фиалко 30 лет назад в сводке подобных комплексов «решила не учитывать полностью ограбленные погребения» [Фиалко, 1991, с. 8]. Как свидетельствуют приведенные данные, в последнее десятилетие она изменила своим «устаревшим» научным принципам, и не только в этом отношении.

Отдельной категорией скифских «амазонок», судя по работам Е.Е. Фиалко, являются дети (девочки) и подростки женского пола. Важно отметить, что пол детей возрастом до 15 лет на основании морфологического изучения костей скелета вообще не определяет- 
ся, а молодых людей в возрасте 15-20 лет - с вероятностью не более 70 \% [Martin, Osterholtz, 2015 , p. 77]. Выход из данной ситуации заключается только в проведении генетических исследований, если сохранность костей удовлетворительная [Krzewińska et al., 2018, table S3, No. 13-22].

Во всех остальных случаях (то есть почти всегда) археологам остается ограничиваться определениями возраста ребенка, подростка или молодого человека, полученными от антропологов на основании изучения сохранившихся зубов. Предполагаемая половая принадлежность устанавливается с учетом сопровождающего инвентаря. Наше мнение как нельзя более соответствует позиции, изложенной Е.Е. Фиалко в 1991 г.: «Говорить о погребениях девочек с оружием пока не представляется возможным из-за полного отсутствия антропологических определений пола детей. Разделение же детских погребений на погребения мальчиков и девочек лишь на основании погребального инвентаря, на наш взгляд, является необоснованным. Нельзя согласиться с мнением, что погребениями девочек считаются те, единственный инвентарь которых представлен бусами или серьгами. Бронзовые, серебряные или золотые серьги встречаются в инвентаре мужских погребений..., точно так же, как и бусины в качестве застежки-украшения... Кроме того, говоря о погребениях девочек с оружием, вряд ли можно принимать в расчет те предметы вооружения, в которых они представлены единственным наконечником стрелы» [Фиалко, 1991, с. 11].

Однако и этот подход «устарел» к настоящему времени. В 2013 г. в серию погребений «амазонок» из Нижнего Поднепровья Е.Е. Фиалко включила ограбленную катакомбу 14 грунтового могильника Скельки [Литвинова, 2011; Попандопуло, 2011], содержавшую, по определению антрополога, кости ребенка возрастом не более двух лет. Среди находок в заполнении сохранились три наконечника стрел, две бусины и свинцовое «пряслице» [Фиалко, 2013, с. 210, рис. 6]. Последнее изделие, безусловно, является ворворкой и имеет массу аналогий в мужских погребениях Северного Причерноморья. Таким образом, никакого женского инвентаря в могиле нет, и судить о половой принадлежности ре- бенка нет никаких оснований, не говоря уже о его принадлежности «племени амазонок».

Спустя два года непотревоженная детская катакомба 3 в кургане 13 могильника Буторы I на левобережье Нижнего Днестра, содержавшая две серьги и фрагментированный наконечник стрелы, была названа «могилой девочки-охранницы Буторского кургана» [Фиалко, 2015, с. 62-63, рис. 27, $A$; 28]. Не оспаривая тот факт, что парные серьги позволяют констатировать женский пол ребенка, заметим, что одного наконечника стрелы совершенно недостаточно, чтобы включать данный погребальный комплекс в список захоронений скифских «амазонок».

Выше мы уже упомянули скифские захоронения Глиное/Водовод, кург. 6, погр. 1; кург. 7, погр. 5; кург. 8, погр. 2; кург. 8, погр. 4; кург. 13, погр. 1; Глиное, кург. 12, погр. 2; кург. 116, погр. 1 на левобережье Нижнего Днестра, свидетельствующие о существовании у скифов традиции размещения стрел поверх тел детей, возле них и на перекрытиях ям. При этом в публикациях этих комплексов данный обряд анализировался, и отмечалось, что он не может указывать на принадлежность детей к воинскому сословию. Этот вывод слишком очевиден, поскольку создать образ детей-воинов и, тем более, девочек-воительниц-«амазонок» может только воспаленное воображение.

Ничуть не меньше фантазии проявлено при атрибуции захоронений взрослых индивидуумов (иногда погребенных вместе с детьми) в качестве захоронений «амазонок».

В заполнении ограбленной катакомбы 49 могильника Скельки в Нижнем Поднепровье был найден один наконечник стрелы, однако его, наряду с определением антрополога (женщина 35-50 лет), оказалось достаточно, чтобы отнести данный комплекс к захоронениям «амазонок» [Фиалко, 2013, с. 207-208, рис. 4,13]. Варианты попадания этого наконечника стрелы в погребение Е.Е. Фиалко, разумеется, не рассматриваются, а они многочисленны (выброшенный грабителями костяк мужчины из катакомбы, причина ранения, случайное попадание предмета с поверхности в силу природных процессов, не связанный с принадлежностью к воинскому сословию элемент обряда, и др.). К сожалению, такие «мелочи» 
не могут остановить опытного исследователя на пути создания все более внушительного списка захоронений скифских «амазонок» Северного Причерноморья.

Другие обстоятельства также не принимаются во внимание. И среди них необходимо отметить отнесение к женскому костяку предметов вооружения, которые были положены другому погребенному. В частности, такая «практика» была использована при анализе катакомбы 39 могильника Скельки. В ней находились костяки женщины 30-35 лет (ожерелье на шее) и ребенка 12-14 лет, по определению антрополога. Между локтями погребенных лежала свинцовая ворворка, названная авторами публикации и вслед за ними Е.Е. Фиалко «пряслицем». У правого бедра ребенка лежали наконечники стрел, при этом его тело находилось справа от женщины [Фиалко, 2013, c. 211 , рис. 8 ], а значит, эти наконечники если и составляли колчанный набор, то принадлежали ребенку, а не женщине. Еще пять наконечников стрел были обнаружены в заполнении камеры, а один найден во входной яме. То есть в данном случае никакой связи между предметами вооружения и женским костяком в катакомбе просто нет. Попытка представить данный комплекс в качестве могилы «амазонки» является элементарным искажением совокупности археологической информации во имя заранее установленной цели, которую необходимо достичь любыми средствами.

Еще одно парное захоронение (№ 24) могильника Скельки (женщины 35-40 лет и полуторагодовалого ребенка, по заключению антрополога), среди инвентаря которого находились лепное пряслице и наконечник копья [Фиалко, 2013, с. 211, рис. 7], также было включено в «когорту» погребений «амазонок». Е.Е. Фиалко обратила внимание на необычное размещение наконечника копья: он был положен на дно погребального сооружения, после чего над ним была сооружена «подушка» из материковой глины, а затем уложена женщина так, что центр пера наконечника копья находился под правым коленом. В результате автор допустила, что «сооружение подножной подушки было обусловлено каким-то физическим изъяном женщины (не исключено, что боевым ранением нижних конечностей)» [Фиалко, 2013, с. 217]. Это предположе- ние, непонятно на чем основанное (все кости поскраниального скелета на чертеже погребения находятся в анатомическом порядке [Попандопуло, 2011, рис. 17,1]), комментировать мы не станем, ибо в этом нет смысла. Но заметим, что более обоснованной представляется версия вотивного характера размещения наконечника копья, тем более в таком необычном месте погребального сооружения. При этом исследователями неоднократно рассматривались нестандартные позиции наконечников копий (вбитых в дно или стены погребальных сооружений, поставленных острием вверх или вниз), интерпретируемые, например, как свидетельства охраны умерших от злых духов, обезвреживания погребенных и т. д. [Бессонова, 1983, с. 48-49; 1984, с. 811; Тельнов и др., 2016, с. 785]. Какая-то из обозначенных версий, несомненно, куда более уместна для объяснения находки наконечника копья в погребении 24 могильника Скельки, чем его интерпретация в качестве захоронения «амазонки».

Противоречит здравому смыслу попытка представить асинхронное захоронение 13 могильника Скельки как погребение «амазонки». Антропологом установлено, что первичным в катакомбе было захоронение мужчины 3540 лет, костяк которого был нарушен при подзахоронении, а вторичным - парное погребение женщины 25-30 лет и новорожденного ребенка, лежавших ближе ко входу в камеру [Фиалко, 2013, с. 214 , рис. 10]. В изголовье погребенных под костями от жертвенной пищи лежали наконечник дротика, его вток и топор. Также были найдены колчанный набор среди костей мужчины, ожерелье на шее женщины и серьга. Подобная ситуация заставила Е.Е. Фиалко сконструировать весьма сложное и неубедительное объяснение того, что оружие якобы принадлежало женщине [Фиалко, 2013, с. 219]. Повторять эти «доводы» мы не будем. Несомненно, их единственное предназначение заключалось в «создании» еще одной скифской «амазонки». Достаточно посмотреть на план погребения, чтобы убедиться, что при подзахоронении костяк мужчины был сдвинут из центра камеры к дальней от входа стенке. Дротик был сломан и вместе с топором брошен к торцевой стенке, поверх этих предметов была положена жертвенная 
пища. Серьга, найденная у правого виска женщины, могла принадлежать и мужчине. Таким образом, инвентарем женщины достоверно является только ожерелье, зафиксированное на ее шее [Попандопуло, 2011, с. 35-36, рис. 13,1].

В погребении 44 могильника Скельки были найдены колчанный набор и кости от жертвенной пищи с ножом. Антропологом было сделано заключение - «женщина? 1822 лет» [Литвинова, 2011, с. 107], что объясняется, как отмечалось выше, возрастом погребенного. В статье Е.Е. Фиалко вопросительный знак исчез: «Женщина 18-22 лет лежала вытянуто на спине, головой на запад» [Фиалко, 2015, с. 206, рис. 3]. Аналогичным образом был решен вопрос с захоронениями в погребении 3 кургана 6 и погребении 1 кургана 71 могильника Мамай-Гора в Нижнем Поднепровье. Антропологические определения («женщина?») для обоих погребений [Литвинова, 1999, с. 190; 2001, с. 253] были слегка исправлены. При этом Е.Е. Фиалко не обратила внимание на то, что погребение 3 кургана 6 было асинхронным (представляло собой катакомбу с двумя входами, в которой похоронили минимум двоих человек), и что оно было ограблено [Фиалко, 2010, с. 188, рис. 1,8]. Тот факт, что сверху над ним находились еще два захоронения (кург. 6, погр. 1 и 2) [Андрух, Тощев, 1999 , с. 48,50 , рис. 12,1$]$, вообще не упоминается. Погребение 1 кургана 71 также было ограблено, и найденные в нем «ниже области черепа» шесть бусин оказались достаточным основанием, чтобы считать комплекс погребением «амазонки» [Фиалко, 2010, c. 192 , рис. 1,1$]$. Таким образом, в результате небольшой и весьма малозаметной «коррекции» заключения антрополога, «возникли» очередные три скифские «амазонки».

Однако исследователь этим не ограничился, поскольку для появления еще одной псевдоамазонки потребовалось оспорить заключение антрополога. Так, ограбленное погребение 26 могильника Скельки, где были обнаружены костяк мужчины (30-35 лет, по заключению антрополога), нож, речная раковина и два наконечника стрел у левого бедра, стало захоронением «амазонки» на основании «необычных» украшений - восьми цилиндрических костяных пронизей, зафиксированных на тазовых костях и вдоль правой ноги. К че- сти автора отметим, что данный комплекс был причислен «К нашей серии» «с определенной долей сомнения» [Фиалко, 2015, с. 213, рис. 9]. Этим «аргументом» остается только восхищаться. Лучше всего данная ситуация описывается афоризмом, приписываемым классику немецкой философии Гегелю: «Если факты противоречат моей теории - тем хуже для фактов».

Однако самое значительное увеличение «поголовья» скифских «амазонок» в последнее время было зафиксировано Е.Е. Фиалко после публикации скифского могильника III-II вв. до н.э. у с. Глиное Слободзейского района на левобережье Нижнего Днестра [Тельнов и др., 2016]. Это «событие» мы не можем оставить без внимания, поскольку авторы данной работы принимали участие в его исследовании, а также поскольку данный памятник находится в непосредственной близости (в 1,7 км к юго-западу) от курганной группы «Сад» у с. Глиное.

Итак, Е.Е. Фиалко «безоговорочно» утверждает, что 16 одиночных женских погребений могильника III-II вв. до н.э. у с. Глиное были захоронениями «амазонок» [Фиалко, 2017, c. 209]. В данной ситуации мы кратко рассмотрим предметы женского инвентаря из каждого комплекса и предметы вооружения, а также укажем возраст погребенных: кург. 6, погр. 2 - парные серьги, предметы ожерелья, один наконечник стрелы справа у таза (2035 лет) [Тельнов и др., 2016, с. 94]; кург. 14, погр. 2 - парные серьги, зеркало, пряслице, топор слева от погребенной рукоятью вниз (более 20 лет) [Тельнов и др., 2016, с. 136]; кург. 41, погр. 1 - парные серьги, ожерелье, два пряслица, один наконечник стрелы у левого локтя, острием в сторону головы (2035 лет) [Тельнов и др., 2016, с. 272]; кург. 46, погр. 3 - ожерелье, три пряслица, два наконечника стрел возле висков остриями вниз (20-35 лет) [Тельнов и др., 2016, с. 294, 296]; кург. 57, погр. 1 - западная камера катакомбы, серьга у левого виска, ожерелье, два пряслица, один наконечник стрелы справа у таза (25-30 лет) [Тельнов и др., 2016, с. 353]; кург. 81, погр. 2 - погребение ограблено, ожерелье, два пряслица, один наконечник стрелы в области шеи (35-50 лет) [Тельнов и др., 2016, с. 483484]; кург. 86, погр. 1 - парные серьги, ожере- 
лье, два пряслица, наконечник копья справа от погребенной (более 20 лет) [Тельнов и др., 2016, с. 508]; кург. 91, погр. 2 - ожерелье, два пряслица, наконечник стрелы у правого плеча (возраст не определен) [Тельнов и др., 2016, с. 537]; кург. 96, погр. 2 - парные серьги, ожерелье, один наконечник стрелы справа от таза (ребенок 13-15 лет) [Тельнов и др., 2016, с. 575]; кург. 109, погр. 1 - парные серьги, ожерелье, два пряслица, один наконечник стрелы между правым локтем и грудной клеткой (2035 лет) [Тельнов и др., 2016, с. 642].

Особо оговорим женские погребения с топором и наконечником копья. Первое из них (кург. 14, погр. 2) было впущено в насыпь «царского» кургана (по меркам III-II вв. до н.э.) [Тельнов и др., 2016, с. 129, рис. 54-59]. Среди инвентаря находилось явно «антикварное» зеркало [Тельнов, Синика, 2014, с. 240-241; Тельнов и др., 2016, с. 895-896; Полин, Дараган, 2019, с. 208-209], а единственный на могильнике двулезвийный топор [Тельнов и др., 2016 , с. 782], с учетом общей длины его навершия (14,6 см), очевидно, являлся инсигнией власти, а не боевым оружием. Какой-то особенный статус был и у женщины, погребенной в катакомбе погребения 1 кургана 86. Справа от нее было положено копье длиной 1,2 м (в непотревоженном комплексе был зафиксирован тлен от древка), наконечник которого, в отличие от всех прочих из мужских погребений могильника, имеет необычную форму [Тельнов и др., 2016, с. 785, 979-980].

Как показывает анализ, из десяти перечисленных комплексов в восьми были найдены наконечники стрел (только в погребении 3 кургана 46 их было два, в остальных комплексах - по одному), в двух других - топор (кург. 14, погр. 2) и копье (кург. 86, погр. 1). Наконечник стрелы из погребения 2 кургана 81, найденный в области шеи вместе с прикипевшими к нему предметами ожерелья, мог являться причиной смерти [Тельнов и др., 2016 , с. 484, 776, рис. 272,8]. Наконечники стрел из катакомбы 3 кургана 46, лежавшие у висков погребенной, очевидно, играли роль отсутствующих серег [Тельнов и др., 2016, с. 775]. В остальных комплексах (кург. 6, погр. 2, кург. 57, погр. 1, кург. 96, погр. 2 - справа у/от таза, кург. 91, погр. 2 - у правого плеча, кург. 41, погр. 1 - у левого локтя, кург. 10 , погр. 1 - у правого локтя) размещение наконечников стрел может отражать определенные элементы погребальной обрядности (размещение стрел поверх тела погребенного или возле него), зафиксированные многократно в мужских, женских и детских погребениях [Тельнов и др., 2016, с. 776]. К близкому выводу пришел и Ю.С. Гребенников при анализе скифских захоронений Побужья: «Женским погребением с оружием можно безоговорочно считать лишь такое, когда в нем, помимо типично женского инвентаря (пряслице, зеркало), имеются меч, копье-дротик или колчан со стрелами. ...Разрозненные наконечники... считать оружием нельзя. Разрозненные наконечники есть во всех погребениях, независимо от пола и возраста. Здесь налицо еще одна специфическая деталь погребального обряда» [Гребенников, 2008, с. 79-80].

В этой связи напомним Е.Е. Фиалко о ее собственном, к сожалению, незаслуженно забытом «принципе»: «говоря о погребениях девочек с оружием, вряд ли можно принимать в расчет те предметы вооружения, в которых они представлены единственным наконечником стрелы. Это, впрочем, касается и погребений женщин с оружием» [Фиалко, 1991, с. 11].

Возвращаясь к могильнику III-II вв. до н.э. у с. Глиное, отметим, что Е.Е. Фиалко увидела скифских «воительниц» в четырех детских («девичьих») захоронениях - кург. 12, погр. 2, кург. 33, погр. 2, кург. 35, погр. 2, кург. 68, погр. 2 [Фиалко, 2017, с. 209]. При этом в одном из них (кург. 33, погр. 2) был похоронен ребенок возрастом 8-9 лет, у его левого бедра лежал колчан с шестью стрелами, но никакого инвентаря, который мог бы указывать на женский пол погребенного, обнаружено не было [Тельнов и др., 2016, с. 232]. В трех других катакомбах действительно были погребены девочки: кург. 12, погр. 2 - парные серьги, ожерелье, один наконечник стрелы справа у таза, другой - возле левого плеча (4 года) [Тельнов и др., 2016, с. 121]; кург. 35, погр. 2 - парные серьги, ожерелье, пряслице, один наконечник стрелы у левого плеча (8-9 лет) [Тельнов и др., 2016, с. 245]; кург. 68, погр. 2 - ожерелье, один наконечник стрелы между ног у правого колена (4-5 лет) [Тельнов и др., 2016, c. 414]. Здесь можно только повторить, что подобные случаи размещения наконечников 
стрел никак не могут указывать на то, что девочки были «воительницами».

Обнаружила Е.Е. Фиалко захоронения «амазонок» еще и в четырех, по ее мнению, парных захоронениях - Глиное, кург. 9, погр. 1, кург. 13, погр. 1, кург. 67, погр. 4, кург. 113, погр. 1 [Фиалко, 2017, с. 209]. Эти комплексы на самом деле являлись асинхронными [Тельнов и др., 2016, с. 669, 672, 743-744]. Однако этот факт был проигнорирован, поскольку требовалось увеличить число погребений «амазонок». Сделано это было в трех случаях с использованием ранее апробированного «метода», когда предметы вооружения, связанные с мужским костяком, приписываются женщине. В катакомбе 1 кургана 9 тело женщины (парные серьги, ожерелье, пряслице) было внесено в камеру при подзахоронении и положено справа от мужчины, у левого бедра которого находился колчанный набор [Тельнов и др., 2016, с. 109-110]. В захоронении 1 кургана 13 три наконечника стрел лежали у правого локтя мужчины (вторичное захоронение), в то время как костяк женщины (парные височные кольца, ожерелье, веретено с пряслицем) находился слева от мужского [Тельнов и др., 2016, с. 122]. Женщина (ожерелье, парные височные кольца) была внесена в катакомбу 4 кургана 67 при подзахоронении, а два наконечника стрел находились между тазом и правым локтем мужчины, костяк которого находился слева от женского [Тельнов и др., 2016, с. 407-409]. В катакомбе 1 кургана 113 при двух погребенных никакого женского инвентаря вообще не было найдено, и здесь нам приходится только догадываться, на каком основании среди них появилась «амазонка».

На этом Е.Е. Фиалко не остановилась. Используя указание, что половая принадлежность погребенных в катакомбах могильника III-II вв. до н.э. определялась не антропологом, а нами, авторами публикации, что соответствует действительности [Тельнов и др., 2016 , с. 80], она констатировала, что «именно поэтому большинство комплексов с оружием попали в число мужских». В итоге к выборке захоронений «амазонок» были добавлены еще 11 погребений (кург. 3, погр. 1, кург. 5, погр. 1, кург. 10, погр. 1, кург. 24, погр. 1, кург. 26, погр. 1, кург. 28, погр. 1, кург. 41, погр. 2, кург. 45, погр. 1, кург. 54, погр. 3, кург. 95, погр. 1, кург. 104, погр. 1). И основанием для этого стало «присутствие в составе вещевого сопровождения бусинных браслетов и/или каменных плиток (помимо оружия)» [Фиалко, 2017, с. 209]. Здесь важно подчеркнуть, что ни в одном из перечисленных комплексов (одиночных мужских захоронений, не пострадавших от ограблений) не было предметов, являющихся типично женским инвентарем (парных серег, ожерелий, зеркал, пряслиц). Каменные плиты, вопреки представлениям Е.Е. Фиалко, известны в мужских захоронениях [Бессонова, Скорый, 1986, с. 158-160, рис. 1,1,2,4; Тельнов и др., 2016, с. 918; Синика, Тельнов, 2017в, с. 145], равно как и браслеты, составленные из бусин. Последние, например, были выявлены в 27 случаях на запястьях мужчин в катакомбах могильника у с. Глиное [Тельнов и др., 2016, с. 863].

Подытоживая свои «штудии», Е.Е. Фиалко выделила 35 погребений могильника, «в которых похоронено 38 воительниц» [Фиалко, 2017 , с. 209-210], и заметила в заключении, «что 35 могил амазонок составляют 19,3\% от общего числа в некрополе и $30 \%$ от числа могил с оружием. Соответственно каждая пятая могила принадлежала воительнице и каждым третьим воином здесь была женщина» [Фиалко, 2017, с. 225]. Эти показатели не только не соответствуют действительности, но и противоречат здравому смыслу, являясь не более чем фантазиями.

Только шесть погребений могильника из перечисленных Е.Е. Фиалко [2017, с. 209] можно считать погребениями женщин-воительниц, при этом пять из них (с наборами от двух до пяти стрел) только с очень большой «натяжкой». В катакомбе 1 кургана 12 была погребена женщина (парные серьги, два пряслица, возраст не определен), у правого бедра которой находились три наконечника стрел [Тельнов и др., 2016, с. 117-119]; в захоронении 1 кургана 19 (три пряслица, возраст 20-35 лет) три наконечника стрел у левого бедра [Тельнов и др., 2016, с. 159, 161]; в погребении 1 кургана 23 (парные серьги, ожерелье, два пряслица, зеркало, возраст более 20 лет) пять наконечников стрел у левого бедра [Тельнов и др., 2016, с. 183-184, 186]; в катакомбе 1 кургана 31 (парные серьги, ожерелье, зеркало, два пряслица, возраст менее 20 лет) - 
два наконечника стрел у левого бедра, топор возле правой голени [Тельнов и др., 2016, с. 211, 215-216]; в комплексе кург. 91, погр. 1 (парные височные кольца, ожерелье, зеркало, два пряслица, возраст 20-35 лет) - три наконечника стрел у левого бедра [Тельнов и др., 2016, c. $532-533,535]$. Только одна катакомба, несомненно, принадлежала женщине-воину. В катакомбе 1 кургана 103 при погребенной возрастом 15-20 лет были найдены парные серьги, ожерелье, зеркало, два пряслица, а также колчанный набор, лежавший у левого локтя и состоявший из 17 наконечников стрел [Тельнов и др., 2016, с. 610-611].

С учетом того, что за все время исследования могильника III-II вв. до н.э. у с. Глиное было изучено 183 катакомбы, предназначавшиеся для захоронений (в том числе одного символического - кенотафа) минимум 282 человек [Тельнов и др., 2016, с. 744; Синика, Тельнов, 2018б], указанные шесть погребений женщин составляют только $3,27 \%$ от общего количества могил и только $2,12 \%$ от общего количества погребенных. И вот эти цифры куда более соответствуют истинному положению вещей, в отличие от фантастического показателя (19,3 \% всех могил - это захоронения «амазонок»), указанного Е.Е. Фиалко [2017, с. 225]. Кроме того, приведенные нами расчеты коррелируют с данными об очень невысокой «милитаризации» скифского общества в III-II вв. до н.э. [Синика, Тельнов, 2015, с. 187-189; Тельнов и др., 2016, c. 786-789], которые, будучи опубликованными до выхода из печати работы Е.Е. Фиалко, либо не были ей известны, либо были сочтены не заслуживающими внимания.

Также необходимо отметить, что подобная картина была зафиксирована в примыкающих друг к другу курганных группах Глиное/Водовод и Глиное/Сад, образовывавших на протяжении V - первой трети III в. до н.э. памятник, который обычно называют могильником. За все время их изучения $(2013,2015-$ 2019 гг.) авторами настоящей работы были раскопаны, помимо более ранних и более поздних, 94 скифских захоронения, предназначавшихся для погребений (в том числе десяти символических - кенотафов) минимум 102 человек. При этом, как отмечено выше, всего четыре могилы (Глиное/Сад, кург. 11, погр. 4; Гли-
ное/Водовод, кург. 10, погр. 3, кург. 11, погр. 3, кург. 16, погр. 5) принадлежали женщинам-воинам, что составляет только $4,25 \%$ от общего количества могил и только $3,92 \%$ от общего количества погребенных. Эти показатели совершенно не «поразительным» образом совпадают с теми, что мы указали для более позднего (III-II вв. до н.э.) могильника у с. Глиное.

Более того, если количество достоверных женских захоронений с оружием (9) могильника Мамай-Гора в Нижнем Поднепровье [Фиалко, 2010], за исключением указанных нами выше (кург. 5, погр. 3, кург. 6, погр. 3, кург. 71, погр. 1) и некорректно отнесенных Е.Е. Фиалко к «амазонкам», сопоставить с общим количеством опубликованных скифских погребальных комплексов этого памятника (317), то в очередной раз мы будем констатировать совершенно не «удивительное» совпадение - 2,83 \%.

Причиной указанных «совпадений», несомненно, является тот факт, что на всех трех памятниках (Глиное/Водовод и Глиное/Сад $\mathrm{V}$ - первой трети III в. до н.э. на левобережье Нижнего Днестра; Мамай-Гора VI-IV вв. до н.э. в Нижнем Поднепровье; Глиное IIIII вв. до н.э. на левобережье Нижнего Днестра) были проведены масштабные работы, результатом которых стало формирование достаточной источниковой базы, позволяющей делать столь точные выводы и одновременно столь категоричные заключения.

Эти выводы в корне противоречат многократно обозначенным заявлениям Е.Е. Фиалко: «В общем массиве скифских погребений с оружием $25 \%$ принадлежит женщинам» [Фиалко, 1991, с. 15]; «в могильнике МамайГора... каждым десятым воином была женщина, и каждая одиннадцатая женщина носила оружие» [Фиалко, 2010, с. 196]; «каждым четвертым воином у скифов Северного Причерноморья была женщина» [Фиалко, 2011, c. 28]; «в Скелянском могильнике отмечен самый большой процент погребений амазонок среди некрополей Степной Скифии. ...В могильнике похоронено 22 воина, половину из которых составляют женщины... каждая вторая женщина носила оружие» [Фиалко, 2013, c. 220]; «в скифской культуре погребения вооруженных женщин составляют более $25 \%$ \% [Фиалко, 2015, с. 90-91]; на некрополе Глиное «каждая пятая могила принадлежала воитель- 
нице и каждым третьим воином здесь была женщина» [Фиалко, 2017, с. 225].

Как нами показано, эти «громогласные» заявления были сделаны на основе некорректного анализа археологических данных (ограбленные погребения, как правило, без антропологических определений; захоронения маленьких детей с предметами вооружения; погребения взрослых с предметами вооружения, которые не могут указывать на воинскую принадлежность; отнесение предметов вооружения, положенных в парных и асинхронных погребениях мужчине, к инвентарю женщин; умышленная «коррекция» и безосновательное оспаривание антропологических определений; использование браслетов из бусин и каменных плит в качестве исключительно женского инвентаря), целью которого, очевидно, являлось формирование корпуса погребений скифских «амазонок» Северного Причерноморья.

Данная попытка явно не удалась: «искусственное вычленение погребений женщин с оружием из общего массива скифских женских погребений, тем более в одном могильнике и даже в одном кургане, и рассмотрение их как особой группы погребений, и тем более их соотнесение с мифическими амазонками (см. работы Е.Е. Фиалко), является абсолютно надуманным и произвольным» [Полин, Дараган, 2019, с. 213].

\section{Заключительные положения}

Курган 11 группы Глиное/Сад, исследованный у с. Глиное на левобережье Нижнего Днестра в 2018 г., содержал материалы, которые представляют интерес для изучения скифской культуры не только Северо-Западного, но и всего Северного Причерноморья. В насыпи, возведенной во второй половине (предпочтительно третьей четверти) IV в. до н.э., было одно детское и три женских захоронения. В каждой женской могиле находилось зеркало. Два из них были положены под тело погребенных, при этом под одним зеркалом, с отломанной в древности ручкой, лежала игла. В изголовье одной из женщин была положена каменная плита, предварительно полностью обожженная. Из комплекса погребения 3 кургана 11 группы Глиное/ Сад происходят парные серьги, одно из окончаний которых оформлено в виде конического утолщения, что свидетельствует о фракийском влиянии на материальную культуру скифов Северо-Западного Причерноморья. В двух погребениях были обнаружены наконечники стрел и одно из них (Глиное/Сад, кург. 11, погр. 4) можно считать погребением женщины-воина.

Последнее обстоятельство заставило авторов настоящей работы проанализировать комплексы скифских «амазонок» Северного Причерноморья. Оказалось, что многие из них таковыми не являются, будучи включенными в список погребений псевдоамазонок в результате грубейших нарушений научной методики, умолчания «ненужных» фактов, искажения совокупности археологической информации или пренебрежения ею.

С учетом огромного накопленного к настоящему времени материала очевидно, что компетентный и непредвзятый анализ комплексов с предметами вооружения позволяет различать три группы скифских захоронений Северного Понта: 1) с предметами вооружения, размещение которых отражает определенные «этнографические» особенности обряда (наконечники стрел, положенные на перекрытие погребального сооружения, поверх или возле тела; топоры, мечи, наконечники копий, боевые ножи, наконечники стрел, вбитые или воткнутые в дно/стенку могилы, а также положенные под тело умершего) или особый статус погребенного, например, являющимися инсигниями власти; 2) с наконечниками стрел, которые могут свидетельствовать об охотничьем промысле (колчанные наборы, состоявшие из двух-пяти стрел); 3 ) погребения воинов с разнообразными и многочисленными предметами вооружения. Во всех трех группах достоверно женские захоронения крайне немногочисленны в процентном соотношении.

\section{ПРИМЕЧАНИЯ}

1 Здесь и далее при указании курганов и погребений в курганных группах «Сад» и «Водовод» у с. Глиное используется как равнозначная следующая конструкция: Глиное/Сад, Глиное/Водовод - где первое слово обозначает наименование населенного пункта, у которого располагается памятник, второе слово - наименование курганной группы.

${ }^{2}$ Определение кандидата биологических наук, младшего научного сотрудника Института зоологии им. И.И. Шмальгаузена НАН Украины (Киев) Е.Ю. Яниш, за что выражаем ей огромную признательность. 


\section{ИЛЛЮСТРАЦИИ}

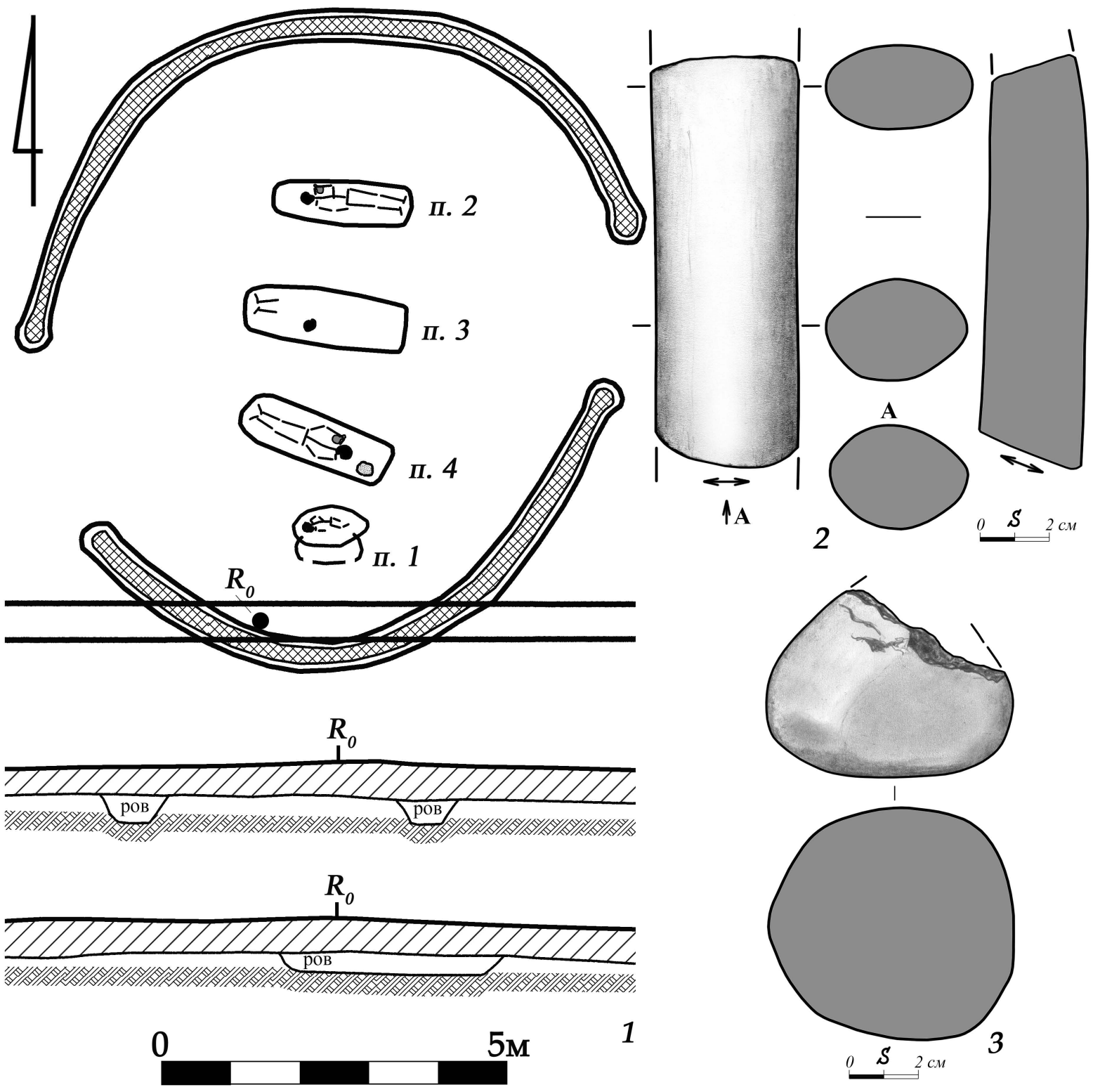

Рис. 1. Курган 11 группы «Сад» у с. Глиное Слободзейского района на левобережье Нижнего Днестра:

1 - план кургана; 2, 3 - находки из насыпи

Fig. 1. Barrow 11 of the "Garden" group near the Glinoe village, Slobodzeya district, on the left bank of the Lower Dniester:

1 - plan of the barrow; 2, 3 - finds from the mound 


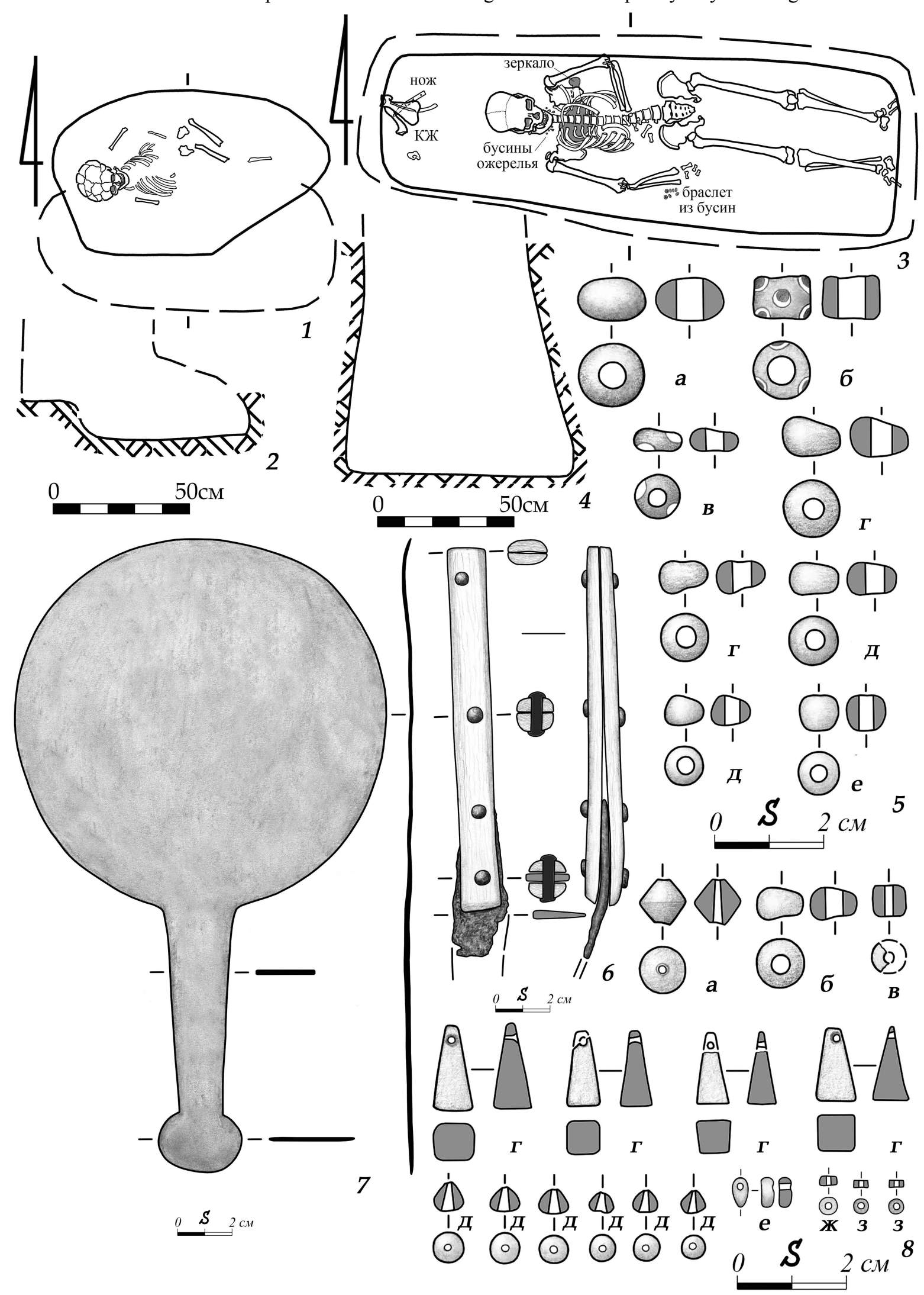

Рис. 2. Погребения 1 и 2 кургана 11 группы «Сад»:

1,2 - план и разрез погребения $1 ; 3,4$ - план и разрез погребения 2; 5-8 - инвентарь погребения 2

Fig. 2. Graves 1 and 2 of the barrow 11 of the "Garden" group:

1,2 - plan and section of burial 1;3,4-plan and section of burial 2; 5-8- grave goods from the burial 2 
Курган 11 группы «Сад» в Нижнем Поднестровье и современное «мифотворчество»

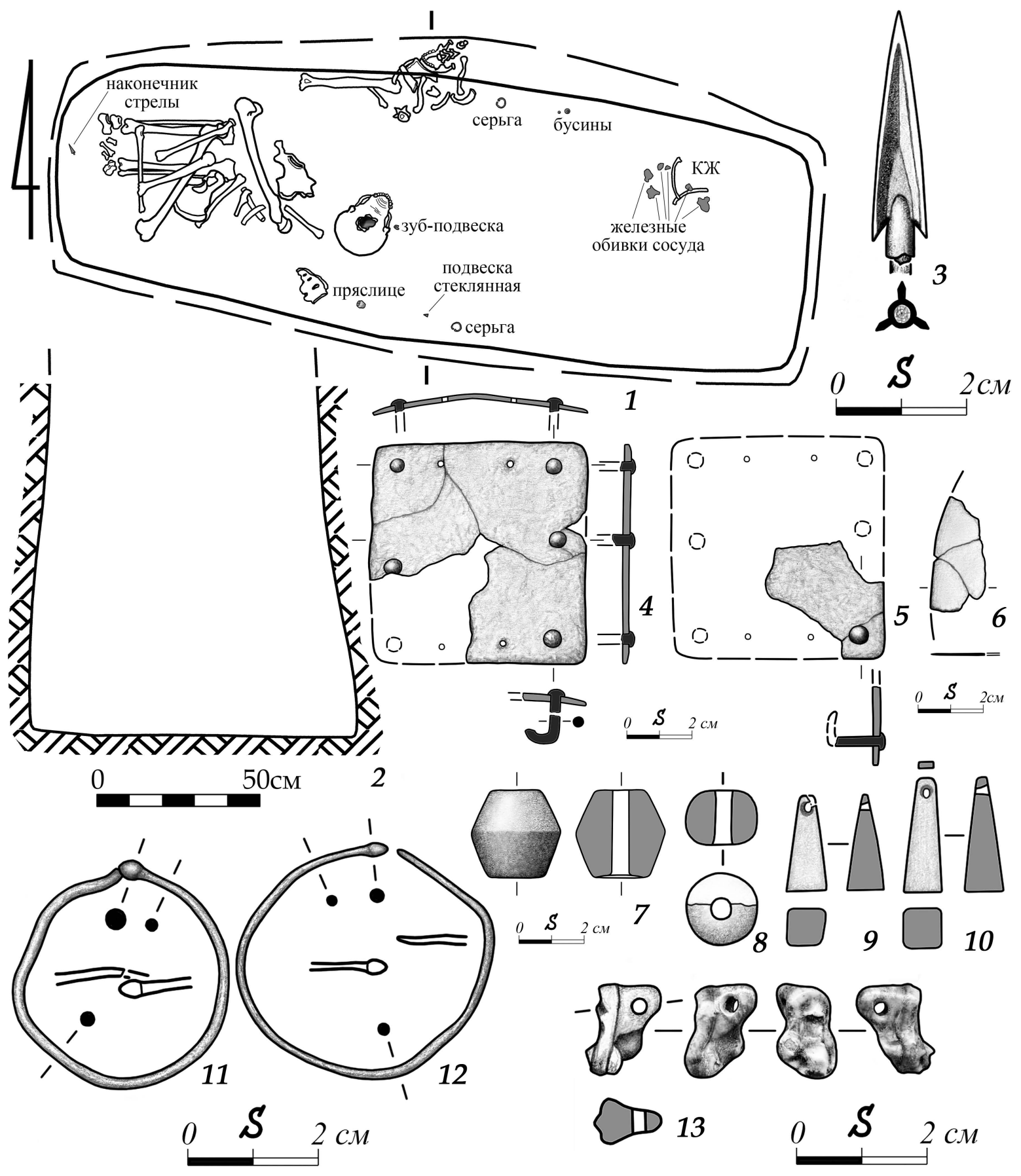

Рис. 3. Погребение 3 кургана 11 группы «Сад»:

1, 2 - план и разрез погребения; 3-13 - инвентарь

Fig. 3. Burial 3 of the barrow 11 of the "Garden" group:

1, 2 - plan and section of the burial; 3-13-grave goods from the burial 
Barrow 11 of the "Garden" Group in the Lower Dniester Region and Contemporary "Mythmaking"

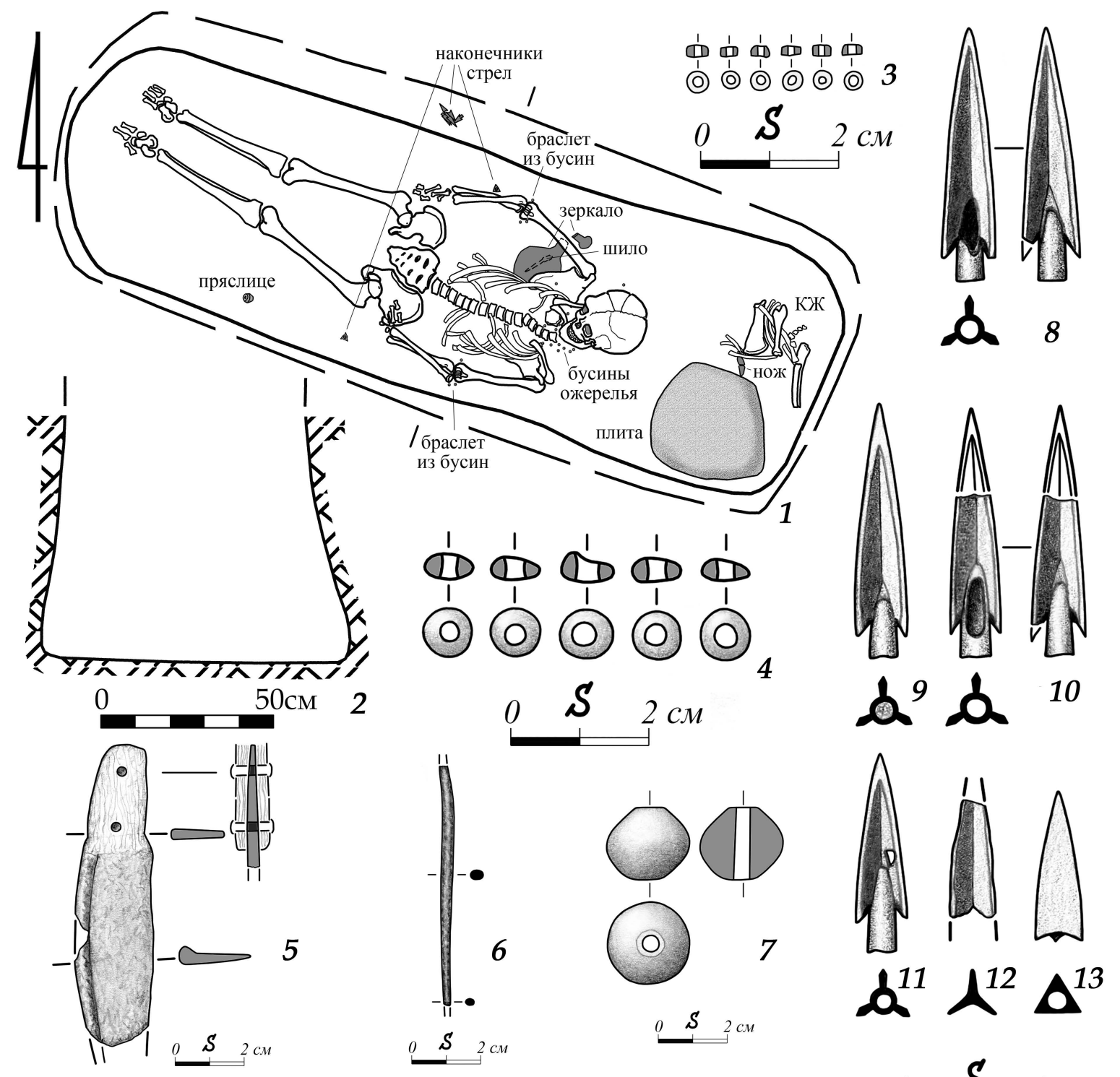

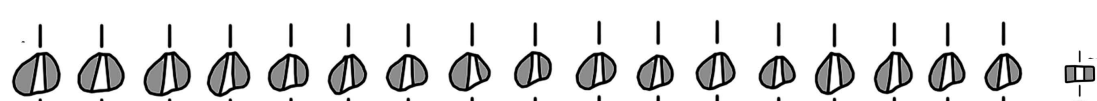

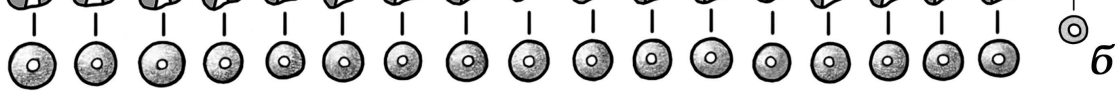

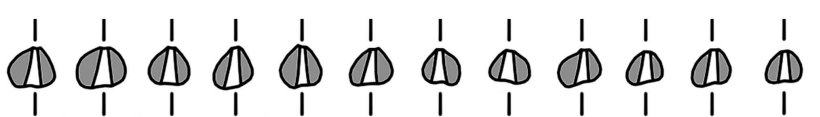

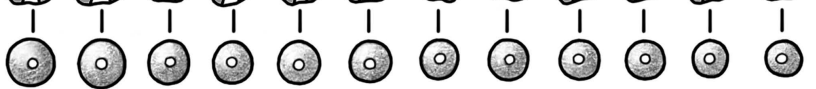
(1) \begin{tabular}{llllllllllllll}
\hline & 1 & 1 & 1 & 1 & 1 & 1 & 1 & 1 & 1 & 1 & 1 \\
0 & 0 & 0 & 0 & 0 & 0 & 0 & 0 & 0 & 0 & 0 & 0
\end{tabular} $0 \quad S \quad 2 c M$

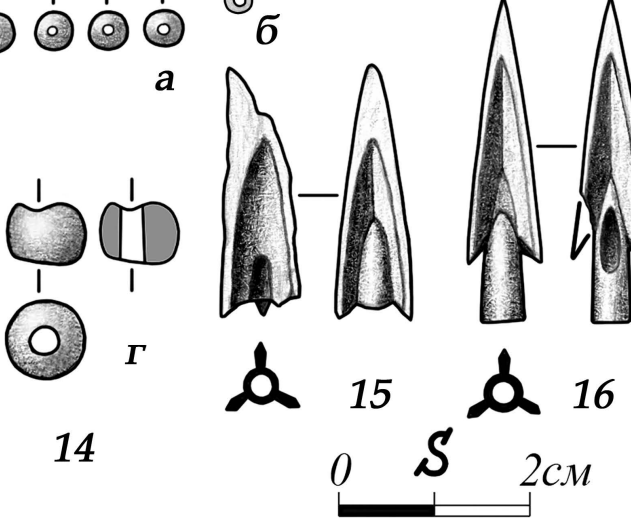

Рис. 4. Погребение 4 кургана 11 группы «Сад»:

1, 2 - план и разрез погребения; 3-16 - инвентарь

Fig. 4. Burial 4 of the barrow 11 of the "Garden" group:

1, 2 - plan and section of the burial; 3-16-grave goods from the burial 
Курган 11 группы «Сад» в Нижнем Поднестровье и современное «мифотворчество»
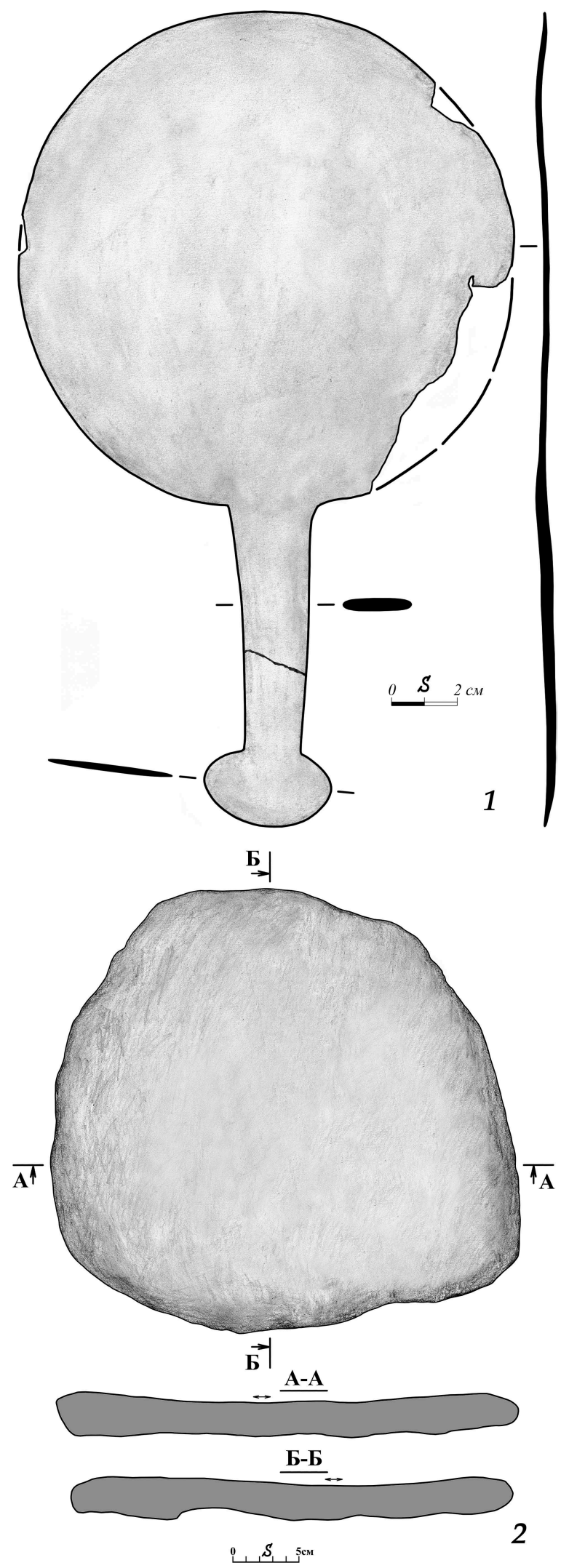

Рис. 5. Бронзовое зеркало (1) и каменная плита (2) из погребения 4 кургана 11 группы «Сад»

Fig. 5. The bronze mirror (1) and the stone slab (2) from the grave 4 of the barrow 11 of the "Garden" group 


\section{СПИСОК СОКРАЩЕНИЙ}

АП УРСР - Археологічні пам'ятки Української Радянської Соціалістичної Республіки. Київ. МИА - Материалы и исследования по археологии СССР. М. САИ - Свод археологических источников СССР. М.

\section{СПИСОК ЛИТЕРАТУРЫ}

Агульников С., Сава Е., 2004. Исследования курганов на левобережье Днестра. Кишинев : CEP USM. 243 с. Алексеева И. Л., 1977. Отчет о раскопках курганов Нижне-Днестровской (новостроечной) экспедицией Института археологии Академии наук УССР в зоне строительства I очереди Нижне-Днестровской оросительной системы (с. Ясски, Беляевский район) // Научный архив Института археологии НАН Украины. № 1976/87. 47 с., 56 ил.

Андрух С. И., Суничук Е. Ф., 1987. Захоронения зажиточных скифов в Низовьях Дуная // Новые исследования по археологии Северного Причерноморья. Киев : Наукова думка. С. 38-46.

Андрух С. И., Тощев Г. Н., 1999. Могильник Мамай-Гора. Кн. І. Запорожье : ИА НАН Украины : Изд-во ЗГУ. $232 \mathrm{c}$.

Бессонова С. С., 1983. Религиозные представления скифов. Киев : Наукова думка. 138 с.

Бессонова С. С., 1984. О культе оружия у скифов // Вооружение скифов и сарматов. Киев : Наукова думка. C. 3-21.

Бессонова С. С., Скорый С. А., 1986. Погребение скифского воина из Акташского могильника в Восточном Крыму // Советская археология. № 4. С. 158-170.

Болтрик Ю. В., Фиалко Е. Е., 2011. Зеркало из кургана Огуз // Восточноевропейские древности скифской эпохи. Вып. 1. Воронеж : Научная книга. С. 85-97.

Ванчугов В. П., Субботин Л. В., Дзиговский А. Н., 1992. Курганы приморской части Днестро-Дунайского междуречья. Киев : Наукова думка. 92 с.

Гребенников Ю. С., 2008. Киммерийцы и скифы Степного Побужья (IX-III вв. до н.э.). Николаев : Илион. $192 \mathrm{c}$.

Гудкова А. В., Суничук Е. Ф., 1985. Полевой отчет Орловского курганного отряда Буджакской археологической экспедиции в 1984 г. // Научный архив Института археологии НАН Украины. № 1984/3a. 103 с., 180 табл.

Гудкова А. В., Тощев Г. М., Фокеев М. М., Андрух С. И., 1985. Отчет о работе Измаильской новостроечной экспедиции в 1984 г. // Научный архив Института археологии НАН Украины. № 1984/158. 124 с.

Дзис-Райко Г. А., 1965. Раскопки могильника в с. Николаевка на Днестровском лимане // Краткие сообщения о полевых исследованиях Одесского государственного археологического музея за 1963 год. Одесса : Маяк. С. 59-68.

Кетрару Н. А., Синика В. С., Разумов С. Н., Тельнов Н. П., 2014. Дубоссарские курганы. Серия: Археологические памятники Приднестровья. II. Тирасполь : Stratum plus. 240 c.

Ковалева И. Ф., 1999. Скифские погребения правобережного Предстепья // Проблемы скифо-сарматской археологии Северного Причерноморья (к 100-летию Б.Н. Гракова). Запорожье : Изд-во ЗГУ. С. 128-131.

Литвинова Л. В., 1999. Антропологический материал из могильника Мамай-Гора // Андрух С. И., Тощев Г. Н. Могильник Мамай-Гора. Кн. І. Запорожье : ИА НАН Украины : Изд-во ЗГУ. С. 188-209.

Литвинова Л. В., 2001. Антропологический материал из могильника Мамай-Гора // Андрух С. И. Могильник Мамай-Гора. Кн. ІІ. Запорожье : ИА НАН Украины : Изд-во ЗГУ. С. 246-271.

Литвинова Л. В., 2011. Антропологический материал из грунтового могильника «Скельки» // Попандопуло 3. Х. Скифский грунтовый могильник Скельки. Запорожье : Запорожский областной краеведческий музей. С. 91-113.

Марченко И. И., 1996. Сираки Кубани (по материалам курганных погребений Нижней Кубани). Краснодар : Изд-во КубГУ. 340 с.

Медведев А. П., 1990. Сарматы и лесостепь (по материалам Подонья). Воронеж : Изд-во Воронеж. ун-та. 220 с. 
Мелюкова А. И., 1962. Скифские курганы Тираспольщины (по материалам И.Я. и Л.П. Стемпковских) // Памятники скифо-сарматской культуры. МИА. № 115. С. 114-166.

Мелюкова А. И., 1964. Вооружение скифов. САИ. Вып. Д1-4. М. : Наука. 92 с., 23 табл.

Мелюкова А. И., 1975. Поселение и могильник скифского времени у с. Николаевка. М. : Наука. 260 с.

Мозолевский Б. Н., 1973. Скифские погребения у с. Нагорное близ г. Орджоникидзе на Днепропетровщине // Скифские древности. Киев : Наукова думка. С. 187-234.

Никитенко И. С., Лысенко С. Д., 2014. Результаты минералого-петрографического анализа изделий из камня могильника Малополовецкое-3 и поселения Малополовецкое-2А (Киевская область) // Stratum plus. № 2. C. 333-344.

Никитин В. И., 2018. Курганы Нижнего Поингулья. Николаев : Илион. 160 с.

Ольховский В. С., 1991. Погребально-поминальная обрядность населения степной Скифии (VII-III вв. до н.э.). М. : Наука. $256 \mathrm{c.}$

Петренко В. Г., 1978. Украшения Скифии VII-III вв. до н.э. САИ. Вып. Д4-5. М. : Наука. 144 с.

Полин С. В., Дараган М. Н., 2019. Зеркала в погребениях геродотовых скифов Северного Причерноморья второй половины V - IV в. до н.э. // Античный мир и археология. Вып. ХIX. Саратов : Техно-Декор. C. 201-241.

Попандопуло 3. Х., 2011. Скифский грунтовый могильник Скельки. Запорожье : Запорожский областной краеведческий музей. 116 с.

Раевский Д. С., 2006. Очерки идеологии скифо-сакских племен. Опыт реконструкции скифской мифологии // Раевский Д. С. Мир скифской культуры. М. : Языки славянских культур. С. 15-262.

Редина Е. Ф., 1999. Скифский могильник Неделково на севере Одесской области // Stratum plus. № 3. С. 75-80.

Савва Е. Н., Агульников С. М., Манзура И. В., 1985. Отчет о полевых исследованиях Буджакской новостроечной экспедиции в 1984 г. // Архив Национального музея истории Молдовы. № 212. 149 с.

Синика В. С., 2007а. Погребальные памятники скифской культуры VII - начала III в. до н.э. на территории Днестро-Прутско-Дунайских степей : автореф. дис. ... канд. ист. наук. М. 28 с.

Синика В. С., 2007б. Погребальные памятники скифской культуры VII - начала III в. до н.э. на территории Днестро-Прутско-Дунайских степей : дис. ... канд. ист. наук. М. 238 с.

Синика В. С., Лысенко С. Д., Тельнов Н. П., 2018а. Скифский курган 9 группы «Сад» на левобережье Нижнего Днестра с литиком «монетного» типа // Причерноморье в античное и раннесредневековое время. Вып. 2. Ростов н/Д : Изд-во Южного Федерального университета. С. 166-176.

Синика В. С., Тельнов Н. П., Лысенко С. Д., 2018б. Скифские погребения кургана 4 группы «Сад» на левобережье Нижнего Днестра // Вестник Нижневартовского государственного университета. № 1. С. 111-119.

Синика В. С., Тельнов Н. П., Лысенко С. Д., 2018в. Скифский курган 7 группы «Сад» в Нижнем Поднестровье // Вестник Воронежского государственного университета. Серия: История. Политология. Социология. № 1. C. 125-138.

Синика В. С., Тельнов Н. П., Лысенко С. Д., 2018г. Скифский курган 8 группы «Водовод» на левобережье Нижнего Днестра // Известия Самарского научного центра РАН. Т. 20, № 3. С. 234-244.

Синика В. С., Тельнов Н. П., Лысенко С. Д., 2018д. Скифский курган 8 группы «Сад» на левобережье Нижнего Днестра // Вестник Нижегородского университета им. Н. И. Лобачевского. № 2. С. 78-93.

Синика В. С., Тельнов Н. П., Лысенко С. Д., 2018е. Скифский курган с детскими погребениями на левобережье Нижнего Днестра // Записки Института истории материальной культуры РАН. Вып. 18. С. 69-79.

Синика В.С., Лысенко С.Д., Тельнов Н.П., Разумов С.Н., 2019а. Скифский курган 7 группы «Водовод» в Нижнем Поднестровье // Stratum plus. № 3. С. 365-390.

Синика В. С., Лысенко С. Д., Разумов С. Н., Тельнов Н. П., 2019б. Скифский курган 10 группы «Водовод» на левобережье Нижнего Днестра // Oriental studies. № 5. C. 822-844. DOI: https://doi.org/10.22162/26190990-2019-45-5-822-844.

Синика В. С., Лысенко С. Д., Тельнов Н. П., Разумов С. Н., 2019в. Скифский курган второй половины V в. до н.э. в Нижнем Поднестровье // Вестник Волгоградского государственного университета. Серия 4, История. Регионоведение. Международные отношения. Т. 22, № 1. С. 6-19. DOI: https://doi.org/10.15688/ jvolsu4.2019.1.1. 
Синика В. С., Тельнов Н. П., Лысенко С. Д., Разумов С. Н., 2019г. Скифское захоронение в нестандартной позе на левобережье Нижнего Днестра // Contribuţii la preistoria şi istoria antică a spaţiului carpato-danubiano-pontic. In honorem professoris Ion Niculiţă natalia sua octogesima celebrantis. Chişinău : Cartididact. C. 281-295.

Синика В. С., Лысенко С. Д., Разумов С. Н., Тельнов Н. П., 2020. Скифское погребение в необычной катакомбе на Нижнем Днестре // Stratum plus. № 3.

Синика В. С., Разумов С. Н., Тельнов Н. П., 2013. Курганы у с. Буторы. Серия: Археологические памятники Приднестровья. І. Тирасполь : Полиграфист. 148 с.

Синика В. С., Разумов С. Н., Тельнов Н. П., 2016. Археологическое наследие Приднестровья. Тирасполь : Полиграфист. $156 \mathrm{c}$.

Синика В. С., Тащи Е. Ф., Тельнов Н. П., Четвериков И. А., 2012. Поселение Красное на левобережье Нижнего Днестра // Stratum plus. № 3. С. 187-215.

Синика В. С., Тельнов Н. П., 2015. Комплекс вооружения и предметов воинского снаряжения из скифского могильника конца IV-II вв. до н.э. у с. Глиное в Нижнем Поднестровье // Война и военное дело в скифосарматском мире : материалы Междунар. науч. конф., посвящ. памяти А. И. Мелюковой (с. Кагальник, 26-29 апреля 2014 г.). Ростов н/Д : Изд-во ЮНЦ РАН. С. 180-190.

Синика В. С., Тельнов Н. П., 2016а. Скифский курган № 1 группы «Водовод» на левобережье Нижнего Днестра // Емінак. № 4 (16). С. 45-53.

Синика В. С., Тельнов Н. П., 2016б. Скифское захоронение с тамгой рубежа IV-III вв. до н.э. с левобережья Нижнего Днестра // Новое прошлое. № 4. С. 258-272.

Синика В. С., Тельнов Н.П., 2016в. Скифское погребение с литиком-скарабеоидом с левобережья Нижнего Днестра // Стародавнє Причорномор'я. XI. Одеса : Одеський національний університет імені I.I. Мечникова. С. 488-499.

Синика В. С., Тельнов Н. П., 2017а. Скифские курганы 2 и 3 группы «Сад» в Нижнем Поднестровье // Новое прошлое. № 4. С. 286-306.

Синика В. С., Тельнов Н. П., 2017б. Скифское погребение с уникальным амулетом с левобережья Нижнего Днестра // Научные ведомости Белгородского государственного университета. Серия: История. Политология. № 8 (257), вып. 42. С. 5-12.

Синика В. С., Тельнов Н. П., 2017в. Скифское погребение с фракийской фибулой на Нижнем Днестре // Stratum plus. № 3. C. 131-152.

Синика В. С., Тельнов Н. П., 2018а. Курган 5 группы «Водовод» на левобережье Нижнего Днестра и скифские кенотафы Северо-Западного Причерноморья // Самарский научный вестник. Т. 7, № 1 (22). С. 133-144.

Синика В. С., Тельнов Н. П., 2018б. Скифский курган 116 первой половины III в. до н.э. у с. Глиное // Древности. Исследования и проблемы : сб. ст. в честь 70-летия Н. П. Тельнова. Кишинев ; Тирасполь : Stratum plus. C. $223-266$.

Синика В. С., Тельнов Н. П., 2018в. Фракийские украшения и аксессуары костюма из скифских погребений левобережья Нижнего Днестра (находки 2016-2017 гг.) // Народы и культуры Нижнего Дуная в древности : материалы Междунар. науч.-практ. конф. (г. Измаил, 23-26 августа 2018 г.). Измаил : Ирбис. C. $163-179$.

Синика В. С., Тельнов Н. П., Закордонец О. А., 2017. Скифский курган № 4 группы «Водовод» на левобережье Нижнего Днестра // Самарский научный вестник. Т. 6, № 2 (19). С. 108-113.

Смирнов К. Ф., 1964. Савроматы (ранняя история и культура сарматов). М. : Наука. 380 с.

Субботин Л. В., Островерхов А. С., Охотников С. Б., Редина Е. Ф., 1992. Скифские древности Днестро-Дунайского междуречья. Киев : Препринт. 48 с.

Субботин Л. В., Разумов С. Н., Синика В. С., 2017. Семеновские курганы. Серия: Археологические памятники Приднестровья. IV. Тирасполь : Stratum plus. 180 c.

Тельнов Н. П., Синика В. С., 2013. Гетское погребение на левобережье Днестра и некоторые проблемы фракийского погребального обряда // Tyragetia. S. n. Vol. VII (XXII). Nr. 1. C. 297-309.

Тельнов Н. П., Синика В. С., 2014. Зеркала из позднескифского могильника конца IV - II в. до н.э. у с. Глиное на левобережье Нижнего Днестра // IV «Анфимовские чтения» по археологии Западного Кавказа. Западный Кавказ в контексте международных отношений в древности и средневековье (г. Краснодар, 28-30 мая 2014 г.). Краснодар : Традиция. С. 239-249. 
Тельнов Н. П., Четвериков И. А., Синика В. С., 2016. Скифский могильник III-II вв. до н.э. у с. Глиное. Серия: Археологические памятники Приднестровья. III. Тирасполь : Stratum plus. 1096 с.

Тереножкин А. И., Ильинская В. А., Черненко Е. В., Мозолевский Б. Н., 1973. Скифские курганы Никопольщины // Скифские древности. Киев : Наукова думка. С. 113-186.

Фиалко Е. Е., 1991. Погребения женщин с оружием у скифов // Курганы Степной Скифии. Киев : Наукова думка. С. 4-18.

Фиалко Е. Е., 2010. Погребения амазонок из могильника Мамай-Гора // Stratum plus. № 3. С. 187-196.

Фиалко Е. Е., 2011. Амазонки Причерноморских степей // Восточноевропейские древности скифской эпохи. Вып. 1. Воронеж : Научная книга. С. 23-37.

Фиалко Е. Е., 2013. Серия погребений амазонок из Нижнего Поднепровья // Straum plus. № 3. С. $203-222$.

Фиалко Е. Е., 2015. Амазонки во времени и пространстве // Археологія і давня історія України. Вип. 4 (17). C. $46-99$.

Фиалко Е. Е., 2017. Серия погребений скифских воительниц в могильнике у с. Глиное (Молдова) // Археологія і давня історія України. Вип. 2 (23). С. 208-227.

Фокеев М. М., 1991. Отчет о раскопках 1990 г. // Научный архив Института археологии НАН Украины. № 1990/61. 23 с., 29 рис.

Чеботаренко Г. Ф., Яровой Е. В., Тельнов Н. П., 1989. Курганы Буджакской степи. Кишинев: Штиинца. 212 с. Яровой Е. В., 1990. Курганы энеолита - эпохи бронзы Нижнего Поднестровья. Кишинев: Штиинца. 272 с.

Băţ M., Zanoci A., Cojocari E., 2019. Tezaurul de piese de podoabă de la Mateuţi: noi date şi interpretări // Contribuţii la preistoria şi istoria antică a spaţiului carpato-danubiano-pontic. In honorem professoris Ion Niculiţă natalia sua octogesima celebrantis. Chişinău : Cartididact. P. 297-322.

Fidelschi S. A., 2006. Dezvoltarea meşteşugului la populaţia sedentară din regiunea Nistrului Inferior (după rezultatele săpăturilor la aşezarea pluristratificată Ciobruciu)// Tiragetia. XV. P. 24-33.

Krzewińska M., Kilinç G. M., Juras A., Koptekin D., Chyleński M., Nikitin A. G., Shcherbakov N., Shuteleva I., Leonova T., Kraeva L. A., Sungatov F. A., Sultanova A. N., Potekhina I., Łukasik S., Krenz-Niedbała M., Dalén L., Sinika V., Jakobsson M., Storå Ja., Götherström A., 2018. Ancient genomes suggest the Pontic-Caspian steppe as the source of western Iron Age Nomads // Science Advances. Vol. 4, No. 10. DOI: 10.1126/ sciadv.aat4457.

Łukasik S., 2019a. Anthropological analysis of human skeletal remains from Glinoe SAD site, Moldova: barrows 1114. Poznań, 10 January 2019. Report submitted to the Taras Shevchenko University in Tiraspol. 6 p.

Łukasik S., 2019b. Anthropological analysis of human skeletal remains from Glinoe Vodovod site, Moldova: barrows 9-16. Poznań, 28 January 2019. Report submitted to the Taras Shevchenko University in Tiraspol. 16 p.

Martin D. L., Osterholtz A. J., 2015. Bodies and lives in ancient America: Health before Columbus. London : Routledge. $176 \mathrm{p}$.

Sinika V. S., Lysenko S. D., Telnov N. P., 2017. Scythian complexes of the barrows 5 and 6 from the "Garden” group on the left bank of the Lower Dniester // Tractus aevorum: эволюция социокультурных и политических пространств. № 4 (2). С. 156-173.

\section{REFERENCES}

Agul'nikov S., Sava E. 2004. Issledovaniya kurganov na levoberezh'e Dnestra [Studies of Barrows on the Left Bank of the Dniester]. Kishinev, CEP USM. 243 p.

Alekseeva I.L., 1977. Otchet o raskopkakh kurganov Nizhne-Dnestrovskoy (novostroyechnoy) ekspeditsiyey Instituta arkheologii Akademii nauk USSR v zone stroitel'stva I ocheredi Nizhne-Dnestrovskoy orositel'noy sistemy (s. Yasski, Belyayevskiy rayon) [Report on Excavations of the Barrowss of the Lower Dniester (Rescue) Expedition of the Institute of Archeology of the Academy of Sciences of the Ukrainian SSR in the Zone in the Building of the First Stage of the Dniester Irrigation System (Yassky Village, Belyaevka District)]. Nauchnyy arkhiv Instituta arkheologii NAN Ukrainy, no. 1976/87. 47 p., 56 fig.

Andrukh S.I., Sunichuk E.F., 1987. Zakhoroneniya zazhitochnykh skifov v Nizov'yakh Dunaya [Graves of the Noble Scythians in the Lower Danube Region]. Novyye issledovaniya po arkheologii Severnogo Prichernomor'ya [New Investigationsinto the Archaeology of Northern Pontic Region]. Kiev, Naukova dumka Publ., pp. 38-46. 
Andrukh S.I., Toshchev G.N., 1999. Mogil'nik Mamay-Gora [Mamai-Gora Cemetery], book I. Zaporizhzhya, IA NASU, Zaporizhzhya National University. $232 \mathrm{p}$.

Bessonova S.S., 1983. Religioznyye predstavleniya skifov [Religious Conceptions of the Scythians]. Kiev, Naukova dumka Publ. $138 \mathrm{p}$.

Bessonova S.S., 1984. O kul'te oruzhiya u skifov [On the Cult of Weapons of the Scythians]. Vooruzheniye skifov i sarmatov [The Armament of Scythians and Sarmatians]. Kiev, Naukova dumka Publ., pp. 3-21.

Bessonova S.S., Skory S.A., 1986. Pogrebeniye skifskogo voina iz Aktashskogo mogil'nika v Vostochnom Krymu [A Burial of a Scythian Warrior from the Aktash Burial Ground in the Eastern Crimea]. Sovetskaya arkheologiya [Soviet Archaeology], no. 4, pp. 158-170.

Boltrik Yu.I., Fialko E.E., 2011. Zerkalo iz kurgana Oguz [Mirror from the Oguz Kurgan]. Vostochnoyevropeyskiye drevnosti skifskoy epokhi [East European Antiquities of the Scythian Era], iss. 1. Voronezh, Nauchnaya kniga Publ., pp. 85-97.

Vanchugov V.P., Subbotin L.V., Dzigovsky A.N., 1992. Kurgany primorskoy chasti Dnestro-Dunayskogo mezhdurech'ia [Barrows of the Coastal Part of Dniester-Danube Interfluve]. Kiev, Naukova dumka Publ. $92 \mathrm{p}$.

Grebennikov Yu.S., 2008. Kimmeriytsy i skify Stepnogo Pobuzh'ia (IX-III vv. do n.e.) [Cimmerians and Scythians of the Steppe Bug Region $\left(9^{\text {th }}-3^{\text {rd }}\right.$ Centuries BC)]. Nikolaev, Ilion Publ. $192 \mathrm{p}$.

Gudkova A.V., Sunichuk E.F., 1985. Polevoy otchet Orlovskogo kurgannogo otryada Budzhakskoy arkheologicheskoy ekspeditsii v 1984 g. [Field Report of the Orlovka Barrow Team, Budzhak Archaeological Expedition, in 1984]. Nauchnyy arkhiv Instituta arkheologii NAN Ukrainy, no. 1984/3a. 103 p., 180 fig.

Gudkova A.V., Toshchev G.M., Fokeev M.M., Andrukh S.I., 1985. Otchet o rabote Izmail'skoy novostroyechnoy ekspeditsii v 1984 g. [Report on the Fieldworks of the Izmail Rescue Expedition in 1984]. Nauchnyy arkhiv Instituta arkheologii NAN Ukrainy, no. 1984/158. 124 p.

Dzis-Rayko G.A., 1965. Raskopki mogil'nika v s. Nikolayevka na Dnestrovskom limane [Excavations of the Cemetery near the Nikolaevka Village on the Dniester Firth]. Kratkiye soobshcheniya o polevykh issledovaniyakh Odesskogo gosudarstvennogo arkheologicheskogo muzeya za 1963 god [Concise Bulletins on the Fieldworks of the Odessa State Archaeological Museum in 1963]. Odessa, Mayak Publ., pp. 59-68.

Chetraru N.A., Sinika V.S., Razumov S.N., Telnov N.P., 2014. Dubossarskiye kurgany. Seriya: Arkheologicheskiye pamyatniki Pridnestrov'ia [Dubossary Barrows. Archaeological Sites of Pridnestrovie]. II. Tiraspol, Stratum plus Publ. 240 p.

Kovalyova I.F., 1999. Skifskiye pogrebeniya pravoberezhnogo Predstep'ya [Scythian Graves of the Right-bank Dnieper Border of the Steppe and Forest-Steppe]. Problemy skifo-sarmatskoy arkheologii Severnogo Prichernomor'ya (k 100-letiyu B.N. Grakova) [Problems of Scythian and Sarmatian Archeology of the Northern Pontic Region). Zaporozhye, Zaporozhye State University, pp. 182-187.

Litvinova L.V., 1999. Antropologicheskiy material iz mogil'nika Mamay-Gora [Anthropological Material from the Mamai-Gora Cemetery]. Andrukh S.I., Toshchev G.N. Mogil'nik Mamay-Gora [Mamai-Gora Cemetery], book I. Zaporozhye, IA NASU, Zaporizhzhya National University, pp. 188-209.

Litvinova L.V., 2001. Antropologicheskiy material iz mogil'nika Mamay-Gora [Anthropological Material from the Mamai-Gora Cemetery]. Andrukh S.I. Mogil'nik Mamay-Gora [Mamai-Gora Cemetery], book II. Zaporozhye, IANASU, Zaporizhzhya National University, pp. 246-271.

Litvinova L.V., 2011. Antropologicheskiy material iz gruntovogo mogil'nika «Skel'ki» [Anthropological Material from the Cemetery Without Mounds "Skel'ki"]. Popandopulo Z.X. Skifskiy gruntovyy mogil'nik Skel'ki [Scythian Cemetery Without Mounds Skel'ki]. Zaporozhye, Zaporizhzhya Regional Museum of Local Lore, pp. 91-113.

Marchenko I.I., 1996. Siraki Kubani (po materialam kurgannykh pogrebeniy Nizhney Kubani) [Kuban Siraces (Basing on the Materials from the Barrow Burials from Lower Kuban Region)]. Krasnodar, Kuban State University. $340 \mathrm{p}$.

Medvedev A.P., 1990. Sarmaty i lesostep' (po materialam Podon'ya) [Sarmatians and Forest-Steppe Zone (on the Materials from the Don River Region)]. Voronezh, Voronezh University. 220 p.

Melukova A.I., 1962. Skifskiye kurgany Tiraspol'shchiny (po materialam I.Ya. i L.P. Stempkovskikh) [Scythian Barrows of the Tiraspokl Region (Based on Materials of I.Ya. and L.P. Stempkovskie)]. Pamyatniki skifosarmatskoy kul'tury. Materialy i issledovaniya po arheologii SSSR, no. 115, pp. 114-166. 
Melyukova A.I., 1964. Vooruzheniye skifov [Scythian Armament]. Svod Arkheologicheskikh Istochnikov, iss. Д1-4. Moscow, Nauka Publ. 92 p., 23 tables.

Melyukova A.I., 1975. Poseleniye i mogil'nik skifskogo vremeni u s. Nikolayevka [Settlement and Necropolis of Scythian Age near the Village of Nikolaevka]. Moscow, Nauka Publ. 260 p.

Mozolevskiy B.N., 1973. Skifskiye pogrebeniya u s. Nagornoye bliz g. Ordzhonikidze na Dnepropetrovshchine [Scythian Graves Near the Nagornoe village Near the Ordzhonikidze City in the Dnipropetrovsk Region]. Skifskiye drevnosti [Scythian Antiquities]. Kiev, Naukova dumka Publ., pp. 187-234.

Nikitenko I.S., Lysenko S.D., 2014. Rezul'taty mineralogo-petrograficheskogo analiza izdeliy iz kamnya mogil'nika Malopolovetskoye-3 i poseleniya Malopolovetskoye-2A (Kiyevskaya oblast') [Results of the Mineralogical and Petrographic Analysis of Stone Goods from the Burial Ground Malopolovetskoye-3 and the Settlement Malopolovetskoye-2A (Kiev Region)]. Stratum plus, no. 2, pp. 333-344.

Nikitin V.I., 2018. Kurgany Nizhnego Poingul'ya [Barrows of the Lower Ingul Region]. Nikolayev, Ilion Publ. 160 p.

Olkhovskiy V.S., 1991. Pogrebal'no-pominal'naya obryadnost' naseleniya stepnoy Skifii (VII-III vv. do n.e.) [The Funerary and Commemorative Rites of the Population of Steppe Scythia ( $7^{\text {th }}-3^{\text {rd }}$ Centuries BC) $]$. Moscow, Nauka Publ. 256 p.

Petrenko V.G., 1978. Ukrasheniia Skifii VII-III vv. do n.e. [Decorations of Scythia: $5^{\text {th }}-3^{\text {rd }}$ Centuries BC]. Svod Arkheologicheskikh Istochnikov, iss. Д4-5. Moscow, Nauka. 144 p.

Polin S.V., Daragan M.N., 2019. Zerkala v pogrebeniyakh gerodotovykh skifov Severnogo Prichernomor'ia vtoroy poloviny V - IV v. do n.e. [Mirrors in the Graves of the Herodotus Scythians of the North Black Sea Region of the Second Half of the $5^{\text {th }}-4^{\text {th }}$ Centuries BC]. Antichnyy mir i arkheologiya [Ancient World an Archaeology], iss. XIX. Saratov, Techno- Décor, pp. 201-241.

Popandopulo Z.Kh., 2011. Skifskiy gruntovyy mogil'nik Skel'ki [Scythian Soil Cemetery Skel'ki]. Zaporozhye, Zaporizhzhya Regional Museum of Local Lore. 116 p.

Rayevskiy D.S., 2006. Ocherki ideologii skifo-sakskikh plemen. Opyt rekonstruktsii skifskoy mifologii [Essays on the Ideology of Scythian-Saka Tribes. Experience in the Reconstruction of Scythian Mythology]. Rayevskiy D.S. Mir skifskoy kul'tury [World of Scythian Culture]. Moscow, Yazyki slavyanskikh kul'tur Publ., pp. 15-262.

Redina E.F., 1999. Skifskiy mogil'nik Nedelkovo na severe Odesskoy oblasti [The Scythian Cemetery Nedelkovo on the North of the Odessa Region]. Stratum plus, no. 3, pp. 75-80.

Savva E.N., Agulnikov S.M., Manzura I.V., 1985. Otchet o polevykh issledovaniyakh Budzhakskoy novostroyechnoy ekspeditsii v 1984 g. [Report on the Fieldworks of the Budzhak Rescue Expedition in 1984]. Arkhiv Natsionalnogo muzeya istorii Moldovy [Archive of the Museum of Archaeology and History of Moldova], no. $212.149 \mathrm{p}$.

Sinika V.S., 2007a. Pogrebal'nyye pamyatniki skifskoy kul'tury VII-nachala III v. do n.e. na territorii DnestroPrutsko-Dunayskikh stepey: avtoref. dis. ... kand. ist. nauk [Funeral Sites of Scythian Culture of the $7^{\text {th }}-$ Beginning of the $3^{\text {rd }}$ Century BC on the Territory of Dniester-Prut-Danube Steppes. Cand. hist. sci. abs. diss.]. Moscow. 28 p.

Sinika V.S., 20076. Pogrebal'nyye pamyatniki skifskoy kul'tury VII-nachala III v. do n.e. na territorii DnestroPrutsko-Dunayskikh stepey: dis. ... kand. ist. nauk [Funeral sites of Scythian Culture of the $7^{\text {th }}$ - beginning of the $3^{\text {rd }}$ Century BC on the territory of Dniester-Prut-Danube steppes. Cand. hist. sci. diss.]. Moscow. 238 p.

Sinika V.S., Lysenko S.D., Tel’nov N.P., 2018a. Skifskiy kurgan 9 gruppy «Sad» na levoberezh’ye Nizhnego Dnestra s litikom «monetnogo» tipa [Scythian Baroow 9 from the "Garden" Group on the Left Bank of the Lower Dniester with the Lithyque of the Coin Type]. Prichernomor'ye v antichnoye i rannesrednevekovoye vremya [Black Sea Region in Ancient and Early Medieval Time], iss. 2. Rostov-on-Don, South federal University, pp. 166-176.

Sinika V.S., Tel’nov N.P., Lysenko S.D., 20186. Skifskiye pogrebeniya kurgana 4 gruppy «Sad» na levoberezh’ye Nizhnego Dnestra [Scythian Burials from Barrow 4 of the "Garden" Group on the Left Bank of the Lower Dniester]. Vestnik Nizhnevartovskogo gosudarstvennogo universiteta [The Bulletin of Nizhnevartovsk State University], no. 1, pp.111-119.

Sinika V.S., Tel'nov N.P., Lysenko S.D., 2018в. Skifskiy kurgan 7 gruppy «Sad» v Nizhnem Podnestrov’ye [Scythian Barrow 7 of the "Garden" Group in Lower Dniester Region]. Vestnik Voronezhskogo gosudarstvennogo universiteta. Seriya: Istoriya. Politologiya. Sotsiologiya [Proceedings of Voronezh State University. Series: History. Political Science. Sociology], no. 1, pp. 125-138. 
Sinika V.S., Tel'nov N.P., Lysenko S.D., 2018г. Skifskiy kurgan 8 gruppy «Vodovod» na levoberezh'ye Nizhnego Dnestra [Scythian Barrow 8 of the "Sluiceway" Group on the Left Bank of the Lower Dniester]. Izvestiya Samarskogo nauchnogo tsentra RAN [Izvestia of Samara Scientific Center of the Russian Academy of Sciences], vol. 20, no. 3, pp. 234-244.

Sinika V.S., Tel'nov N.P., Lysenko S.D., 2018д. Skifskiy kurgan 8 gruppy «Sad» na levoberezh’ye Nizhnego Dnestra [Scythian Barrow 8 of the "Garden" Group on the Left Bank of the Lower Dniester]. Vestnik Nizhegorodskogo universiteta im. N. I. Lobachevskogo [Vestnik of Lobachevsky University of Nizhni Novgorod], no. 2, pp. 78-93.

Sinika V.S., Tel'nov N.P., Lysenko S.D., 2018e. Skifskiy kurgan s detskimi pogrebeniyami na levoberezh'ye Nizhnego Dnestra [Scythian Barrow with Children's Burials on the Left Bank of the Lower Dniester]. Zapiski Instituta istorii material'noy kul'tury RAN [Notes of the Institute of the History of Material Culture of the Russian Academy of Sciences], iss. 18, pp. 69-79.

Sinika V.S., Lysenko S.D., Tel'nov N.P., Razumov S.N., 2019a. Skifskiy kurgan 7 gruppy «Vodovod» v Nizhnem Podnestrov'ye [Scythian Barrow 7 of the "Vodovod" Group in the Lower Dniester Region]. Stratum plus, no. 3, pp. 365-390.

Sinika V.S., Lysenko S.D., Razumov S.N., Tel'nov N.P., 20196. Skifskiy kurgan 10 gruppy «Vodovod» na levoberezh'e Nizhnego Dnestra [Scythian Barrow 10 of the Vodovod "Sluiceway" Group on the Left Bank of the Lower Dniester]. Oriental studies, no. 5. DOI: https://doi.org/10.22162/2619-0990-2019-45-5-822-844.

Sinika V.S., Lysenko S.D., Tel'nov N.P., Razumov S.N., 2019в. Skifskiy kurgan vtoroy poloviny V v. do n.e. v Nizhnem Podnestrov'e ["New" Scythian Complex of the $3^{\text {rd }}$ Century BC on the Right Bank of the Lower Dniester Region]. Vestnik Volgogradskogo gosudarstvennogo universiteta. Seriya 4. Istoriya. Regionovedeniye. Mezhdunarodnyye otnosheniya [Science Yournal of Volgograd State University. History. Area Studies. International Relations], vol. 22, no. 3, pp. 6-19. DOI: https://doi.org/10.15688/jvolsu4.2019.1.1.

Sinika V.S., Tel'nov N.P., Lysenko S.D., Razumov S.N., 2019r. Skifskoye zakhoroneniye v nestandartnoy poze na levoberezh'e Nizhnego Dnestra [Scythian Grave in a Non-Standard Position on the Left Bank of the Lower Dniester]. Contribuţii la preistoria şi istoria antică a spațiului carpato-danubiano-pontic. In honorem professoris Ion Niculiţă natalia sua octogesima celebrantis. Chişinău : Cartididact Publ., pp. 281-295.

Sinika V.S., Lysenko S.D., Razumov S.N., Tel'nov N.P., 2020. Skifskoye pogrebeniye v neobychnoy katakombe na Nizhnem Dnestre [Scythian Grave in Unusual Catacomb in the Lower Dniester]. Stratum plus, no. 3.

Sinika V.S., Razumov S.N., Tel'nov N.P., 2013. Kurgany u s. Butory [Barrows Near Butory Village]. Seriya: Arkheologicheskiye pamyatniki Pridnestrov'ia. I. Tiraspol', Poligrafist Publ. 148 p.

Sinika V.S., Razumov S.N., Tel'nov N.P., 2016. Arkheologicheskoye naslediye Pridnestrov'ya [Archaeological Heritage of Pridnestrovie]. Tiraspol', Poligrafist Publ. $156 \mathrm{p}$.

Sinika V.S., Tashchi E.F., Tel'nov N.P., Chetverikov I.A., 2012. Poseleniye Krasnoye na levoberezh'e Nizhnego Dnestra [Krasnoe Settlement on the Left Bank of the Lower Dniester]. Stratum plus, no. 3, pp. 187-215.

Sinika V.S., Tel'nov N.P., 2015. Kompleks vooruzheniya i predmetov voinskogo snaryazheniya iz skifskogo mogil'nika kontsa IV - II v. do n.e. u s. Glinoye v Nizhnem Podnestrov'ye [A Comlex of Armament and Items of Warrior's Outfit from the Scythian Burial Field of the late $4^{\text {th }}-2^{\text {nd }}$ Centuries BC Near the Village of Glinoe in the Lower Dniester]. Voyna i voyennoye delo v skifo-sarmatskom mire: materialy Mezhdunar. nauch. konf., posvyashch. pamyati A.I. Melyukovoy (s. Kagal'nik, 26-29 aprelya 2014 g.) [The War and the Military in the ScythianSartmatian World. Proceedings of International Scientiic Conference in Tribute to the Memory of A.I. Melyukova (Kagal'nik, 26-29 April 2014)]. Rostov-on-Don, Southern Scientific Center of the Russian Academy of Sciences, pp. 180-190.

Sinika V.S., Tel'nov N.P., 2016a. Skifskiy kurgan № 1 gruppy «Vodovod» na levoberezh’ye Nizhnego Dnestra [Scythian Barrow 1 of the "Vodovod" Group on the Left Bank of the Lower Dniester]. Eminak, no. 4 (16), pp. 45-53.

Sinika V.S., Tel'nov N.P., 2016б. Skifskoye zakhoroneniye s tamgoy rubezha IV-III vv. do n.e. s levoberezh'ia Nizhnego Dnestra [Scythian Burial With Tamga of the Turn of the $4^{\text {th }}-3^{\text {rd }}$ Centuries BC from the Left Bank of the Lower Dniester]. The New Past, no. 4, pp. 258-272.

Sinika V.S., Tel'nov N.P., 2016в. Skifskoye pogrebeniye s litikom-skarabeoidom s levoberezh'ya Nizhnego Dnestra [Scythian Grave with Lithique from the Left Bank of the Lower Dniester]. Starodavne Prichornomor'ya. XI. Odesa, Odesa national university named after I.I. Mechnikov, pp. 488-499.

Sinika V.S., Tel'nov N.P., 2017a. Skifskiye kurgany 2 i 3 gruppy «Sad» v Nizhnem Podnestrov’e [Scythian Barrows 2 and 3 from the "Garden" Group in the Lower Dniester Region]. The New Past, no. 4, pp. $286-306$. 
Sinika V.S., Tel'nov N.P., 2017б. Skifskoye pogrebeniye s unikal'nym amuletom s levoberezh'ya Nizhnego Dnestra [Scythian Burial with Unique Amulet from the Left bank of The Lower Dniester]. Nauchnyye vedomosti Belgorodskogo gosudarstvennogo universiteta. Seriya: Istoriya. Politologiya [Belgorod State University Scientific Bulletin. History. Political Science], iss. 42, no. 8 (257), pp. 5-12.

Sinika V.S., Tel'nov N.P., 2017в. Skifskoye pogrebeniye s frakiyskoy fibuloy na Nizhnem Dnestre [The Scythian Grave With Fibula of the Thracian Type from the Lower Dniester Region]. Stratum plus, no. 3, pp. 131-152.

Sinika V.S., Tel'nov N.P., 2018a. Kurgan 5 gruppy «Vodovod» na levoberezh'e Nizhnego Dnestra i skifskiye kenotafy Severo-Zapadnogo Prichernomor'ya [Barrow 5 of the "Vodovod" Group on the Left Bank of the Lower Dniester and Scythian Cenotaphs of the North-West Black Sea Region]. Samarskiy nauchnyy vestnik [Samara Scientific Bulletin], vol. 7, no. 1 (22), pp. 133-144.

Sinika V.S., Tel'nov N.P., 20186. Skifskiy kurgan 116 pervoy poloviny III v. do n.e. u s. Glinoye [Scythian barrow 116 of the first half of the $3^{\text {rd }}$ century BC near Glinoe village]. Drevnosti. Issledovaniya i problemy: sb. st. v chest' 70-letiya N. P. Tel'nova [Antiquities. Studies and Issues: Essays in Honour of Nicolai Telnov on the Occasion of his $70^{\text {th }}$ Birthday]. Kishinev; Tiraspol, Stratum plus, pp. 223-266.

Sinika V.S., Tel'nov N.P., 2018в. Frakiyskiye ukrasheniya i aksessuary kostyuma iz skifskikh pogrebeniy levoberezh'ya Nizhnego Dnestra (nakhodki 2016-2017 gg.) [Thracian Adornmernts and Costume Accessories from Scythian Graves on the Left Bank of the Lower Dniester (finds of 2016-2017)]. Narody i kul'tury Nizhnego Dunaya v drevnosti: materialy Mezhdunar. nauch.-prakt. konf. (g. Izmail, 23-26 avgusta 2018 g.) [Peoples and Cultures of the Lower Danube in Antiquity. Materials of the International Scientific and Practical Conference (Izmail, August 23-26, 2018).]. Izmail, Irbis Publ., pp. 163-179.

Sinika V.S., Tel'nov N.P., Zakordonets O.A., 2017. Skifskiy kurgan № 4 gruppy «Vodovod» na levoberezh’e Nizhnego Dnestra [Scythian Barrow 4 of the "Sluiceway" Group on the Left Bank of the Lower Dniester]. Samarskiy nauchnyy vestnik [Samara Scientific Bulletin], vol. 6, no. 2 (19), pp. 108-113.

Smirnov K.F., 1964. Savromaty (rannyaya istoriya i kul'tura sarmatov) [Sauromatians. Early History and Culture of Sarmatians]. Moscow, Nauka Publ. 380 p.

Subbotin L.V., Ostroverkhov A S., Okhotnikov S.B., Redina E F., 1992. Skifskiye drevnosti Dnestro-Dunayskogo mezhdurech'ia [Scythian Antiquities of the Dniester-Danube Interfluve]. Kiev, Preprint Publ. 48 p.

Subbotin L.V., Razumov S.N., Sinika V.S., 2017. Semenovskiye kurgany [Semyonovka Barrows]. Seriya: Arkheologicheskiye pamyatniki Pridnestrov'ia. IV. Tiraspol, Stratum plus. 180 p.

Tel'nov N.P., Sinika V.S., 2013. Getskoye pogrebeniye na levoberezhye Dnestra i nekotoryye problemy frakiyskogo pogrebalnogo obryada [The Getae Burial on the Left Bank of the Dniester and Some Problems of the Thracian Burial Practice]. Tyragetia. S. n., vol. VII (XXII), no. 1, pp. 297-309.

Tel'nov N.P., Sinika V.S., 2014. Zerkala iz pozdneskifskogo mogil'nika kontsa IV - II v. do n.e. u s. Glinoye na levoberezh'ye Nizhnego Dnestra [Mirrors from the Late Scythian Cemetery of the End of the $4^{\text {th }}-2^{\text {nd }}$ Centuries BC Near Glinoe Village on the Left Bank of the Lower Dniester]. IV «Anfimovskiye chteniya» po arkheologii Zapadnogo Kavkaza. Zapadnyy Kavkaz v kontekste mezhdunarodnykh otnosheniy $v$ drevnosti $i$ srednevekov'e (g. Krasnodar. 28-30 maya 2014 g.) [The 4 "Anfimov Readings" on the Archeology of the Western Caucasus. The Western Caucasus in the Context of International Relations in the Antiquity and the Middle Ages (Krasnodar, May28-30, 2014).]. Krasnodar, Tradiciya Publ., pp. 239-249.

Tel'nov N.P., Chetverikov I.A., Sinika V.S., 2016. Skifskiy mogil'nik III-II vv. do n.e. u s. Glinoye [Scythian Cemetery of the $3^{\text {rd }}-2^{\text {nd }}$ Centuries BC near the Glinoe Village]. Seriya: Arkheologicheskiye pamyatniki Pridnestrovia. III. Tiraspol, Stratum plus. $1096 \mathrm{p}$.

Terenozhkin A.I., Il'inskaya V.A., Chernenko E.V., Mozolevskiy B.N., 1973. Skifskiye kurgany Nikopol'shchiny [Scythian Barrows of the Nikopol Region]. Skifskie drevnosti [Scythian Antiquities]. Kiev, Naukova dumka Publ., pp. 113-186.

Fialko E.E, 1991. Pogrebeniya zhenshhin s oruzhiem u skifov [Women Graves with Weapon]. Kurgany Stepnoy Skifii [Barrows of the Steppe Scythia]. Kiev, Naukova dumka Publ., pp. 4-18.

Fialko E.E., 2010. Pogrebeniya amazonok iz mogil'nika Mamay-Gora [Amazons‘ Tombs from Mamay-Gora Cemetery]. Stratum plus, no. 3, pp. 187-196.

Fialko E.E., 2011. Amazonki Prichernomorskikh stepey [Amazons of the Black Sea Steppes]. Vostochnoyevropeyskiye drevnosti skifskoy epokhi [Eastern European Antiquities of the Scythian Epoch], iss. 1. Voronezh, Nauchnaya kniga Publ., pp. 23-37.

Fialko E.E., 2013. Seriya pogrebeniy amazonok iz Nizhnego Podneprov’ya [A Series of Amazons' Burials from the Lower Dnieper Area]. Straum plus, no. 3, pp. 203-222. 
Barrow 11 of the "Garden" Group in the Lower Dniester Region and Contemporary "Mythmaking"

Fialko E.E., 2015. Amazonki vo vremeni i prostranstve [Amazons in the Time and Space]. Arheologiya i davnya istoriya Ukraïni [Archaeology and Ancient History of the Ukraine], iss. 4 (17), pp. 46-99.

Fialko E.E., 2017. Seriya pogrebeniy skifskikh voitelnits v mogilnike u s. Glinoye (Moldova) [A Series of Scythian Female Warrior's Burials from the Cemetery Near Glinoe Village (Moldova)]. Arheologiya i davnya istoriya Ukraïn [Archaeology and Ancient History of the Ukraine], iss. 2 (23), pp. 208-227.

Fokeev M.M., 1991. Otchet o raskopkakh 1990 g. [Report on the Excavations of 1990]. Archive of the Archaeology Institute of the Ukraine National Academy of Sciences, no. 1990/61. 23 p., 29 fig.

Chebotarenko G.F., Yarovoy E.V., Telnov N.P., 1989. Kurgany Budzhakskoy stepi [Barrows of the Budyak Steppe]. Kishinev, Shtiitsa Publ. 212 p.

Yarovoy E.V., 1990. Kurgany eneolita - epokhi bronzy Nizhnego Podnestrov'ia [Barrows of Eneolithic and Bronze Age in theLower Dniester Region]. Kishinev, Shtiitsa Publ. 272 p.

Băț M., Zanoci A., Cojocari E., 2019. Tezaurul de piese de podoabă de la Mateuți: noi date şi interpretări. Contribuții la preistoria şi istoria antică a spațiului carpato-danubiano-pontic. In honorem professoris Ion Niculiță natalia sua octogesima celebrantis. Chişinău, "Cartididact" Publ., pp. 297-322.

Fidelschi S.A., 2006. Dezvoltarea meşteşugului la populația sedentară din regiunea Nistrului Inferior (după rezultatele săpăturilor la aşezarea pluristratificată Ciobruciu). Tiragetia, XV, pp. 24-33.

KrzewińskaM., Kilinç G.M., Juras A., Koptekin D., Chyleński M., Nikitin A.G., Shcherbakov N., Shuteleva I., Leonova T., Kraeva L.A., Sungatov F.A., Sultanova A.N., Potekhina I., Lukasik S., Krenz-Niedbała M., Dalén L., Sinika V., Jakobsson M., Storå Ja., Götherström A., 2018. Ancient genomes suggest the Pontic-Caspian steppe as the source of western Iron Age Nomads. Science Advances, vol. 4, no. 10, eaat4457 (2018): doi: 10.1126/sciadv.aat4457.

Łukasik S., 2019. Anthropological analysis of human skeletal remains from Glinoe SAD site, Moldova: barrows 1114. Poznań, 10 January 2019. Report submitted to the Taras Shevchenko University in Tiraspol. 6 p.

Łukasik S., 2019. Anthropological analysis of human skeletal remains from Glinoe Vodovod site, Moldova: barrows 9-16. Poznań, 28 January 2019. Report submitted to the Taras Shevchenko University in Tiraspol. $16 \mathrm{p}$.

Martin D.L., Osterholtz A.J., 2015. Bodies and lives in ancient America: Health beforeColumbus. London, Routledge. $176 \mathrm{p}$.

Sinika V.S., Lysenko S.D., Telnov N.P., 2017. Seriya pogrebeniy skifskikh voitelnits v mogilnike u s. Glinoye (Moldova) of the barrows 5 and 6 from the «Garden» group on the left bank of the Lower Dniester. Tractus aevorum, no. 4 (2), pp. 156-173.

\section{Information About the Authors}

Vitalij S. Sinika, Candidate of Sciences (History), Scientific Laboratory "Archaeology", Pridnestrovian State University, 25 October St., 107, 3300 Tiraspol, Pridnestrovie, Moldova, sinica80@mail.ru,https://orcid.org/0000-0002-1621-9205

Sergey D. Lysenko, Candidate of Sciences (History), Department of the Chalcolithic and the Bronze age, Institute of Archaeology, National Academy of Sciences of Ukraine, Prosp. Geroev Stalingrada, 12, 04210 Kiev, Ukraine, suraganga@yandex.ru, https://orcid.org/0000-0001-9624-0364

Sergey N. Razumov, Candidate of Sciences (History), Scientific Laboratory "Archaeology", Pridnestrovian State University, 25 October St., 107, 3300 Tiraspol, Pridnestrovie, Moldova, razum_22@rambler.ru, https://orcid.org/0000-0001-6030-9390

Nikolaj P. Telnov, Candidate of Sciences (History), Department of Antique and Medieval Archeology, Institute of Cultural Heritage, Ministry of Education, Culture and Research, Stefan cel Mare Bd., 1, 2001 Kishinev, Moldova, telnov_nikolai@mail.ru, https://orcid.org/0000-0001-6878-0216

Sylwia Lukasik, PhD, adjunct, Department of Human Evolutionary, Biology Institute of Anthropology, Adam Mickiewicz University, Umultowska, 89, 61-614 Poznań, Poland, lukasik@amu.edu.pl, https://orcid.org/0000-0003-2210-7434 


\section{Информация об авторах}

Виталий Степанович Синика, кандидат исторических наук, заведующий научноисследовательской лабораторией «Археология», Приднестровский государственный университет, ул. 25 Октября, 107, 3300 г. Тирасполь, Приднестровье, Молдова, sinica80@mail.ru, https://orcid.org/0000-0002-1621-9205

Сергей Дмитриевич Лысенко, кандидат исторических наук, старший научный сотрудник отдела энеолита - бронзового века, Институт археологии Национальной академии наук Украины, просп. Героев Сталинграда, 12, 04210 г. Киев, Украина, suraganga@yandex.ru, https://orcid.org/0000-0001-9624-0364

Сергей Николаевич Разумов, кандидат исторических наук, старший научный сотрудник научно-исследовательской лаборатории «Археология», Приднестровский государственный университет, ул. 25 Октября, 107, 3300 г. Тирасполь, Приднестровье, Молдова, razum_22@rambler.ru, https://orcid.org/0000-0001-6030-9390

Николай Петрович Тельнов, кандидат исторических наук, заведующий Отделом античной и средневековой археологии, Институт культурного наследия Министерства образования, культуры и исследований, бульвар Штефан чел Маре, 1, 2001 г. Кишинев, Молдова, telnov_nikolai@mail.ru,https://orcid.org/0000-0001-6878-0216

Сильвия Лукасик, $\mathrm{PhD}$, адъюнкт Отдела эволюционной биологии человека, Институт антропологии, Университет им. А. Мицкевича, ул. Умултовска, 89, 61-614 г. Познань, Польша, lukasik@amu.edu.pl,https://orcid.org/0000-0003-2210-7434 